\title{
Preferences, Constraints, and the Process of Sex Segregation in College Majors: \\ A Choice Analysis
}

\author{
Fabian Ochsenfeld \\ Goethe University \\ Institute for Sociology \\ Theodor-W.-Adorno-Platz 6 \\ 60323 Frankfurt, Germany \\ Phone: +49.69 .789 .36631$ \\ E-mail: ochsenfeld@soz.uni-frankfurt.de
}

Post-print published as:

Ochsenfeld, Fabian (2016): Preferences, Constraints, and the Process of Sex Segregation in College Majors: A Choice Analysis. Social Science Research 56: 117-132.

doi:10.1016/j.ssresearch.2015.12.008 


\begin{abstract}
The persistence of horizontal sex segregation in higher education continues to puzzle social scientists. To help resolve this puzzle, we analyze a sample of college entrants in Germany with a discrete choice design that allows for social learning from the experiences of others. We make at least two contributions to the state of research. First, we test whether essentialist gender stereotypes affect major selection mostly through internalization or rather as external constraints that high school graduates adapt their behavior to. Empirically, we find that internalized vocational interests better explain gendered major choices than conformance with friends' and parents' expectations does. Second, we scrutinize whether segregation results from women's anticipation of gendered family roles or from their anticipation of sex-based discrimination, but we find no evidence for either of these hypotheses. As in most previous studies, differences in mathematics achievement fail to explain gendered patterns of selection into college majors.
\end{abstract}

Key words: sex segregation, higher education, vocational preferences, norms, gender. 


\section{Introduction}

Over the past decades, women have made considerable inroads into higher education, employment, and professional careers aided by the institutionalization of egalitarian gender norms across states, organizations and families. However, this dramatic social change has not been paralleled by a comparable integration of women into traditionally male-dominated occupations to date. This presents a puzzle to social scientists partly because occupational segregation is among the key remaining obstacles that prevent the achievement of full economic gender equality (Petersen and Morgan, 1995; Gartner and Hinz, 2009). Since the choice of a college major strongly determines a person's occupational trajectory, and the distribution of women and men across disciplines is both remarkably unequal and inert (Gerber and Cheung, 2008; Barone 2011; DiPrete and Buchmann, 2013), sex segregation across fields of study contributes significantly to the separation of women from men in the labor market (Smyth and Steinmetz, 2008). In this paper, we test competing explanations of why women and men continue to select different majors in college and thereby contribute to resolving the puzzle presented by persistent occupational sex segregation.

Much of the segregation literature is structured along the distinction between supply-side and demand-side factors. Although this distinction has been criticized (Charles and Grusky, 2004), distinguishing between behavioral differences that stem from differences in preferences and differences in constraints individuals face (Gambetta 1987; Zeng and Xie, 2008) is key for informing policy about whether to direct efforts towards schools and the way they shape aspirations (Legewie and DiPrete, 2014a) or instead towards removing constraints women face in the labor market (Reskin and Roos, 1990; Goldin, 2014). Distinguishing between preferences and constraints also renders our study informative for interpreting the large number of studies on gender wage gaps that decompose gender differences into 'explained' and 'unexplained' parts where authors routinely interpret results under the assumption that the explained part was more acceptable than the residual part, from a normative perspective (Blau and Kahn, 2007). Such conclusions would be invalidated if we were to find that the separation of women from men in college majors occurred due to external constraints and against their preference for other potentially more lucrative fields. Furthermore, distinguishing between constraints and preferences allows for connecting the narrower question about major choices to the larger debate in social theory concerning the role of norms (i.e. constraints) versus values (i.e. preferences) for social order (Parsons, 1935; Wrong, 1961; Stigler and Becker, 1977; Vaisey, 2010). 
For the past decade, sociologists have argued that advanced industrial societies combine an essentialist gender culture with liberal individualism such that students come to interpret the choice of their college major as an opportunity for self-realization and expressive assertion of their male or female gender identity (Correll, 2001; Charles and Bradley, 2002; 2009; Charles and Grusky, 2004; Cech, 2014). Based on the argument that sex segregation results from the "indulgence of gendered selves" (Charles and Bradley, 2009), rather than from normative or material constraints, scholars predict that sex segregation will stay at its current high levels because, in a culture that celebrates individual choice, sex segregation as a result of internalized preferences is regarded a legitimate form of inequality that does not conflict with principles of gender egalitarianism (Grusky and Levanon, 2008; Cech, 2014). In line with this argument, recent studies show that differences in men's and women's occupational and educational plans (Mann and DiPrete, 2013; Morgan et al., 2013) account for a large share of horizontal segregation in college.

Although informative, these explanations beg the question why it is that women's plans diverge from men's. It could be that women expect to work in other vocational domains because they have a preference to do other jobs than men, but it could just as well be that they anticipate specific external constraints they will face later in life and therefore decide against domains they would otherwise aspire to work in (Kerckhoff, 1976; Vaisey, 2010). Even though the premise that sex segregation in college majors does not result from constraints is central to essentialism theory, we know of no study that would explicitly scrutinize this claim. To fill this research gap, we here present a model of college major selection that includes three distinct constraints as predictors:

First, we test whether certain fields are perceived as less hospitable to women and avoided by them for that reason. Second, we scrutinize whether women and men anticipate the demands imposed by gender-specific parenthood roles and eschew majors that are incompatible with these either because majors do not provide the desired work-family balance, or not the earnings level necessary to fulfill the breadwinner role. Third, we test whether women's and men's choices are constrained by friends' and parents' potential disapproval for sex-atypical choices. We here provide empirical tests for these hypotheses but - to foreshadow our results - find that these explanations wield much less explanatory power than preference-based essentialism theory.

Methodologically, we apply direct measures of vocational interests and job values that allow us to distinguish between differences in choices that result from gendered preferences 
and differences that result from gendered constraints whereas most previous studies that use large surveys were bound by data limitations to infer to differences in preferences from stated choices (Xie and Shauman, 1997; Shauman, 2006; Beffy et al., 2012, Morgan et al. 2013, but see Legewie and DiPrete, 2014b).

The bulk of earlier research has analyzed women's and men's choices by reducing them to decisions for or against a field in the science, technology, engineering, and mathematics (STEM) group (Correll, 2001; Xie and Shauman, 2003; Legewie and DiPrete, 2014b; Glass and Sassler, 2013) or only slightly less broad fields of study (Ma, 2011; Beffy et al., 2012; Morgan et al., 2013; Gabay-Egozi et al., 2014), reflecting the fact that this is where women are most underrepresented. Although this strategy has produced a significant body of insights, dichotomizing the decision between majors in this vain (1) glosses over potential differences within the STEM group of subjects as well as (2) within the non-STEM group and (3) exaggerates differences between STEM and non-STEM fields in segments where they overlap. We address this shortcoming by adopting a discrete-choice modeling strategy that allows us to effectively generalize our research question from women's underrepresentation in STEM to the unequal distribution of women and men across all college majors whilst preserving the information that is usually lost when majors are merged into broad groups.

Furthermore, previous studies either measured major (or occupation) characteristics and assumed that individual-level mechanisms correspond to observed choices (Xie and Shauman, 1997; Shauman, 2006; 2009; Beffy et al. 2012) or they measured individual-level characteristics and assumed that major characteristics correspond to stated choices (Ma, 2011; Mann and DiPrete, 2013; Morgan et al., 2013; Cech, 2014; Legewie and DiPrete, 2014b). Our strategy of measuring both characteristics of majors and of individuals and specifying their match in the model combines the strengths of the two approaches to provide an even more rigorous analysis of the micro-level processes that underlie horizontal sex segregation. 


\section{Explanations}

To account for the startling persistence of sex segregation in college, social scientists have suggested a wealth of theories. Some explain the phenomenon primarily on the basis of gender stereotypes (gender essentialism), others on the basis of the household division of labor (separate spheres), while again others focus on unfair treatment in the labor market (anticipated discrimination). In the following, we will discuss these three approaches in turn. For gender essentialism and for the separate spheres conjecture, we distinguish between variants of these arguments that are grounded in a culturalist (i.e. preference-based) theory of action $(2.1 .1 ; 2.2 .1)$ and such that are based on a rationalist (i.e. constraint-based) theory of action $(2.1 .2 ; 2.2 .2)$. For anticipated discrimination (2.3) we do not make this distinction as it unambiguously represents a constraint-based explanation.

\subsection{Gender essentialism}

Sociologists and psychologists have put forward essentialism theory that sees the choice of a college major as an instance where individuals behave in accordance with societal expectations of what constitutes gender-appropriate behavior.

\subsubsection{Essentialist preferences and abilities}

In its most popular variant, gender essentialism is thought to operate largely on the basis of preferences: culturally dominant stereotypes learned during childhood and adolescence guide the development of strongly gendered tastes and self-perceptions based on which women and men form systematically different vocational interests and divergent preferences for college majors (Charles and Bradley, 2002; 2009; Cech, 2014). The cultural association of analytical and physical tasks with masculinity on the one hand, and care work and artistic tasks with femininity on the other, is thought to play a pivotal role in this process. Parents have a gender-biased perception of their childrens' abilities and pass on these distorted beliefs concerning competencies to their offspring (Baker and Entwisle, 1987) so that net of their actual ability in these tasks, girls and boys come to assess their abilities differently (Eccles et al., 1990, Correll, 2001). A wealth of studies demonstrates that various mechanisms translate such gender bias in self-perception into sex segregated educational choices:

First, because boys feel more competent in math, they more frequently opt for math activities and courses in school whereas girls disproportionally turn to courses that foster other skills (Correll, 2001). In this manner, by the time of transition into college essentialist stereotypes have manifested into divergent relative advantages in ability that drive boys 
towards math-intensive fields, and girls towards less formalized 'people-oriented' disciplines (Jonsson, 1999; Wang et al. 2013). Studies that have scrutinized this argument, however, show that differences in math ability can play at best a very partial role in the explanation of sex segregation in college (Jonsson, 1999; Xie and Shauman, 2003; Hyde et al., 2008; Lörz et al., 2011; Ma, 2011; Riegle-Crumb et al., 2012; Mann and DiPrete, 2013; Morgan et al. 2013; Zafar, 2013; Legewie and DiPrete, 2014b; but see Turner and Bowen, 1999).

Second, and mediated through the beliefs and behavior of parents, gendered cultural expectations lead men and women to develop self-concepts and interests that differ systematically with regards to a broad range of activities (Baker and Entwisle, 1987; Eccles et al., 1990). A large body of psychological research confirms that women are substantially more interested in social and artistic activities, whereas men more frequently indicate interest in technical and scientific tasks (Su et al., 2009 for a review). Mann and DiPrete (2013) show that gender differences in test scores and life goals fail to account for the underrepresentation of women in STEM majors and interpret the unexplained gap as an effect of gendered preferences. Morgan et al. (2013) estimate that differences in occupational plans explain 23 percent of gender differences in STEM major selection, net of performance, preparation, and work-family goals. Gendered preferences are thought to complement constraints to bring about the unequal distribution of the sexes across college majors. However, it remains unclear whether differences in educational choices explained by expectations can indeed be interpreted as effects of gendered preferences because gender differences in expectations and plans could as well be due to specific constraints women and men face (Kerckhoff, 1976; Vaisey, 2010). Legewie and DiPrete (2014b) apply measures for adolescents' work and study plans that more clearly reflect preferences than measures for expectations do. These explain at least 41 percent of women's lower propensity to choose a science or engineering degree. Zafar (2013) who has precise measures available for a small sample of sophomores from a single university finds that 27 percent of the gender gap in engineering is due to gender differences in beliefs about enjoying coursework.

Underlying both the preference and the ability mechanism is the assumption that individuals internalize gender stereotypes at some point during school and then express their acquired gender identity by opting for sex-typical majors in college. The conception of gendered choices as a form of expressive behavior is a crucial feature of the essentialism conjecture because it puts the theory in the position to provide a plausible explanation for the persistence of horizontal sex segregation despite seemingly countervailing egalitarian trends 
in liberalizing societies and to predict its continued importance in the future: In the highly individualistic cultural contexts prevalent in most affluent countries, essentialist segregation continues to be viewed as a legitimate form of inequality because it results from deliberate individual decisions rather than involuntary adaptation to external social or economic constraints (Grusky and Levanon, 2008; Charles and Bradley, 2009; Cech, 2014). The validity of this explanation and the prediction of stability, however, hinges on the crucial assumption that women's and men's choices indeed express different preferences rather than genderspecific constraints.

\subsubsection{Essentialist norms}

Social scientists invoke the possibility of gender-specific constraints when they argue that society enforces gender norms through sanctioning deviant behavior (i.e. gender-atypical major choices) with social disapproval (Blake and Davis, 1964; Brennan et al., 2013). In this vain, women and men could be channeled into systematically different majors purely by conforming to expectations in their social environment but without internalizing them. They would merely behave differently because they face different (dis)incentives. ${ }^{\mathrm{i}}$ Although segregation scholars frequently refer to this potential mechanism (Jacobs, 1989; Xie and Shauman, 2003: 48; Charles and Grusky, 2004: Ch.1; Charles and Bradley 2009: 929; Blau et al., 2010: 169), we only know of a single study that has assessed empirically to what degree men and women actually factor gender bias in the distribution of potential approval into their choices of a field of study: Zafar (2013) subjected 141 sophomores to a discrete choice design that allows for the separation of social norm effects from preference effects and other potential confounders and finds that differences in expected approval from parents explain only 6.5 percent of the gender gap in choosing economic sciences and almost none of that in engineering. To adjudicate between the preference-based and the constraint-based strands of essentialism theory, we use a larger, nationally representative sample and a more fine-grained scheme of college majors to potentially corroborate this finding.

\subsection{Separate spheres}

Whereas gender essentialism refers to the stereotyping of educational and work contents, horizontal sex segregation in college can also be explained against the backdrop of the fact that men and women historically have assumed different roles in the household and partly continue to do so. Whereas men primarily adopt a breadwinner role, women provide unpaid 
care work and manage the chores of running a household either instead of or in addition to formal employment in the labor market (Davis and Greenstein, 2004).

\subsubsection{Separate spheres: gendered preferences}

The first, preference-based strand of this separate spheres argument holds that such gender roles become internalized during childhood and lead women and men to select college majors that are in line with their respective gender identities (Hakim, 2000; Charles and Grusky, 2004: 22). The argument is premised on differences in preferences rather than constraints: Due to their traditional breadwinner role, men value material rewards more highly than women and aspire to jobs and occupations that allow them to provide for a spouse and a family (Beutel and Marini, 1995; Shu and Marini, 1998; Lips, 2004; Duffy and Sedlacek, 2007). During the 1970 s and ' 80 s women came to embrace careers as part of their identity and increasingly entered 'investment related' majors such as business administration rather than focusing merely on 'consumption related' fields such as literature or home economics (Wilson and Boldizar, 1990; Goldin, 2006), but because this convergence was never completed, traditional gender attitudes persist into the present (Cotter et al., 2011). Since college majors strongly vary in the degree to which they promise high incomes to students (van de Werfhorst and Kraaykamp, 2001; Glocker and Storck, 2014; Ochsenfeld, 2014), gender differences in work-lifestyle preferences could contribute to horizontal sex segregation. In line with this argument Montmarquette et al. (2002) show that women respond significantly less to changes in college majors' earnings potential than men do. Zafar (2013: 571) finds that pecuniary aspects of the workplace explain as much as four times of the choice for males than do non-pecuniary aspects whereas for women's choices both aspects are equally important. A number of empirical studies have, however, disappointed high flying hopes for the explanatory power of job values and life goals for occupational sex segregation (Pollmann-Schult, 2009; Ma, 2011; Busch, 2013; Mann and DiPrete, 2013; Morgan et al., 2013). Cech's study (2014) is specifically designed to separate the effects of traditional gender role beliefs from essentialist self-conceptions and demonstrates that the latter predict where men and women are placed in the spectrum of sex-segregated occupations whereas the former have little effect.

\subsubsection{Separate spheres: gendered constraints}

A second strand of the separate spheres argument rejects the claim that segregation results from differences in internalized goals. Instead, women and men are thought to pursue 
identical preferences such as maximizing lifetime earnings but due to their primary responsibility for childrearing, women face additional constraints and therefore make different occupational choices. In the first, classical formulation of this hypothesis, authors focused mainly on women's need to reconcile work and family in a sequential manner and suggested that women choose occupations that minimize the wage penalty for employment interruptions (Becker, 1975; Polachek, 1981). More recent contributions have shifted attention to the challenge of juggling family and work responsibilities synchronically. They point out that professions allow for different degrees of work-family compatibility through periods of part-time work and flexibility during the work day. Because women have to factor workplace flexibility into their career choice more than men do, such differences across occupations and across time help explain the feminization of mother-friendly professions (Goldin and Katz, 2011). More specifically, these studies emphasize the importance of work organization and the associated norms that regulate hours of work for women's career choices (Bertrand et al., 2010; Goldin and Katz, 2011; 2012; Goldin, 2014). Cha (2013) finds that overwork cultures are much more prevalent in male-dominated occupations, lead to higher attrition rates among mothers, but not fathers, and thereby reinforce sex segregation.

\subsection{Anticipated discrimination}

Following Gary Becker's (1957) classical formulation of the problem, sex segregation researchers consider the possibility that women eschew certain fields because they expect to be constrained by sex-based discrimination (Turner and Bowen, 1999: 297; Xie and Shauman 2003: 2; Blau et al., 2010: Ch.7). Because women are not disadvantaged everywhere (Morgan, 2008) and perceived discrimination is higher in male-dominated disciplines (Steele et al., 2002), anticipated unfair treatment could potentially contribute to the reproduction of horizontal sex segregation in college. Almost unanimously, however, references to this mechanism have been accompanied by cautionary warnings against the difficulty of testing it empirically (Charles and Grusky, 2004: 14; Mann and DiPrete, 2013: 1532; but see Xie and Shauman, 1997). We therefore only know of a single study that has managed to scrutinize the hypothesis but finds that gender differences in beliefs about future earnings entirely fail to explain sex segregation in college majors (Zafar, 2013). 


\section{Data and modeling strategy}

We here conceive of sex segregation in college as the cumulative result of all enrollment decisions that individuals make upon transition from high school to college based on their preferences for characteristics of majors and on constraints associated with majors. This basic conception of the selection process leads us to adopt a discrete choice design where we observe (a) a person's choice for a college major, (b) a set of person characteristics, namely gender, job values, high-school grades, vocational preferences, and (c) a set of theoretically relevant college major characteristics. In the following we describe the three data sets and the various measures which we use in order to model (a) as the outcome of the interplay between (b) and (c).

\subsection{Person characteristics}

For information about individuals' major selections, preferences, and educational preparation, we draw on the German National Educational Panel Study (NEPS), an integrated set of seven nationally representative longitudinal studies of some 40,000 individuals from seven different age cohorts (Blossfeld et al., 2011). We use data from the first and third wave of starting cohort 5 (NEPS-SC5), a panel study of a nationally representative sample of firstyear undergraduate students who were contacted both by mail and directly at central firstsemester courses starting in October 2010, which, for the vast majority of programs, marks the very beginning of first semester courses. The study uses stratified cluster sampling with a degree program at a certain college as the cluster and stratification by type of institution to oversample teaching tracks and private universities and by fields of study to reproduce the distribution of students across fields of study within institutional types (Aßmann et al. 2011). Throughout our analysis, we apply weights provided by the data supplier that account for this complex sampling design and for attrition.

Because our research question refers to the transition from high school to college, we restrict our sample to persons who were not older than 25 years in 2010. German colleges are stratified into two types: full universities (Universitäten) and so called universities of applied sciences (Fachhochschulen) where the latter offer mostly programs in engineering, management, and social work, but not in the humanities, natural sciences, medical or social sciences. A minority of students in Germany graduate from high school with non-standard leaving certificates: The "Fachhochschulreife" allows students to enter the few majors that are offered at universities of applied sciences whereas the "fachgebundene Hochschulreife" 
restricts even the options students have at these lower-tier colleges but instead allows students to enter a very small number of majors at full universities. Both of these types of non-standard leaving certificates categorically exclude students from the majority of majors that are available to students with a "allgemeine Hochschulreife", the standard leaving certificate. Because this would open up highly heterogeneous choice sets, we restrict our sample to individuals with the standard leaving certificate ( 83 percent in our sample). ${ }^{\text {ii }}$

The dependent variable in all conditional logit models reported below is the major a person chose, recorded as a variable that takes on the value 1 in one of the 23 majors that each person chooses among and 0 in the remaining 22 spells. In NEPS-SC5 majors are classified using the Federal Statistical Office's 2-digit classification scheme.

To assess students' preferences for different tasks, we use RIASEC-scores, a widely-used measure in personal psychology to gauge vocational interests (Holland, 1985). The RIASEC scores categorize interests into six distinct interest dimensions: "realistic", "investigative", “artistic”, “social”, “entrepreneurial”, and "conventional”. Respondents were asked to rate how much they "are interested in or enjoy" carrying out 18 different tasks, three for each RIASEC-dimension (table A1). From these, we computed the six RIASEC scores as composite indices with a range between 0 and 1 . We confirmed satisfactory inter-item correlations and orthogonality of the six dimensions by factor analysis.

We measure relative math performance as the difference between a person's last math grade in high school and last German literature grade. In Germany, grades vary between 0 (worst) and 15 (best) so that our measure potentially ranges from -15 to 15 . Positive values indicate relative strength in math, negative ones relative weakness. We also tested for gender differences in both subjects as stand-alone variables and for extreme performance (Penner and Paret, 2008), which did not change our results.

We draw on a set of 6-point Likert-scaled items that were used to survey which aspects respondents personally deem "important to a vocational activity" to measure job values and test the separate spheres conjecture. We use the importance of "good remuneration" to measure variation in the degree to which respondents have internalized a 'breadwinner role'. To account for gender differences in anticipation of work-family conflict, we draw on the item that measures the importance of "pleasant working hours" in vocational activity. Both variables are scaled to a range between 0 and 1 . Missing values were handled through 
casewise deletion $(\mathrm{N}=174)$ which did not significantly skew our sample $(\mathrm{N}=9,109)$ with regards to observables (table A2).

\subsection{Major characteristics}

The factors relevant for testing the separate spheres and anticipated discrimination hypotheses refer to differences between college majors in their general earnings potential, overwork norms, and the degree of labor market discrimination against women, respectively. We assume that high school graduates form their expectations about these differences in response to the experiences of a previous cohort of college-trained workers which they learn about through social networks and other sources (Freeman, 1971; Manski, 1993). To measure these major characteristics, we draw on the German Micro Census, the HIS graduate panel studies, and NEPS-SC5. These are particularly well-suited for our purposes because they provide mutually complementary information while applying the same detailed measure for college major. This allows us to combine them without loss of information.

Because most major characteristics we use are group means generated from individuallevel information, these could potentially be affected by measurement error due to sampling error. Obviously, information generated for small majors is more vulnerable to sampling error because the population means are estimated from fewer cases than those of large fields. We took two measures to cope with this potential source of error. First, to increase sample sizes, we joined small majors with other majors where this seemed substantively justified (see table A3). Second, we restricted the choice set to majors that allow for the computation of aggregate measures on the basis of at least 100 observations. This removes a heterogeneous group of very small majors from the choice set which were chosen in total by 5.51 percent of students in our sample. ${ }^{\text {iii }}$ We also ran our analyses with these small majors merged into a $24^{\text {th }}$ residual major which did not change our results (see tables A4, A5).

For information about the wage levels and work norms of majors, we pool data from the German Micro Census of the years 2007, 2008, and 2009. The Micro Census is organized by the Federal Statistical Office and surveys a 1\% random sample of the residential population of Germany (Schimpl-Neimanns and Herwig, 2011). Respondents are obliged by law to participate and to respond to all items. We apply sampling weights as provided by the Federal Statistical Office throughout our analysis to account for the stratified sampling design. We estimate the wage levels of college majors by linear regression of (logged) hourly wages of college-educated individuals (age 25 to 55; working at least 20 hours per week; $N=60,521$ ) on 
a vector of productivity related characteristics and a vector of major dummies (table A6). ${ }^{\text {iv }}$ The estimated coefficients for the major dummies thus measure the conditional wage levels of respective majors (as the difference to economic sciences, the reference category, in percentage points; see table A7 for the exponentiated coefficients).

To measure overwork norms, we use information on hours worked (top coded at 80 hours per week) by full-time working graduates of the respective majors from the pooled Micro Census $(\mathrm{N}=50,621)$. To complement this objective measure with a subjective indicator, we draw on the HIS graduate panel studies 1997 and 2001, two nationally representative twowave panel studies of stratified random samples of graduates from the German system of higher education (Fabian and Minks, 2006; Fabian and Briedis, 2009). In contrast to the Micro Census, the HIS surveys ask respondents about their personal satisfaction with a broad range of job characteristics. As a measure for work-life compatibility, we constructed a composite index based on three items that measure personal satisfaction with (a) "organization of working time", (b) "family friendliness", and (c) "room for private life" in current employment $(\alpha=.75)$. Because the indicator is highly correlated on the major level $(\mathrm{r}=-$ .80) with hours worked, we only use the objective measure in our analysis, taking the strong correlation with subjective dissatisfaction as evidence for its validity.

We use the proportion of women who indicated in the HIS surveys that "the 'right' gender" is "very important" or "important" "in order to be successful when looking for a $j o b$ " to measure discrimination against women as perceived by those who graduated from college in 1997 and 2001.

Because neither the Census nor the HIS surveys provide information about the mathintensity of majors, we draw on the third wave of NEPS-SC5 where respondents after their first semester were asked "In your studies, how much are abilities and knowledge in the following domains needed?: Mathematics" and indicated their response on a four-point Likert scale. For each major, we aggregated responses to an index with a potential range from 0 to 100. In addition, we coded social work, pedagogy, state teacher, psychology and medical science as care-related majors and all other majors as not care-related.

At the beginning of their first year of study, respondents in NEPS-SC5 were asked to rate the appropriateness of the statements "My parents think that I choose a good field of study" and "My friends think that I choose a good field of study" on a five-point Likert scale. We draw on these items to construct measures for varying degrees of gender bias in social 
approval from parents and friends across majors. To this end we compute the proportion of females and males who either "fully agreed" or "rather agreed" to the above sentences and take the difference between the approval rate for females and the approval rate for males as our measure for norms. Fields where parents and friends reward women more highly with approval thus have positive values and fields where men get more approval than women have negative values. ${ }^{\mathrm{v}}$

\subsection{Modeling strategy}

The theories reviewed above suggest competing explanations for why women and men sort into systematically different college majors but they share a common analytical structure: A person's gender is thought to cause the development of a person characteristic (e.g. relative strength in math) that in turn causally effects the propensity to choose a college major with a trait that matches the person characteristic (e.g. math intensity. Also see figure 8). Previous studies have adopted one of two alternative strategies to model these pathways:

One set of studies (Lörz et al., 2011; Ma, 2011; Mann and DiPrete, 2013; Morgan et al., 2013; Cech, 2014; Gabay-Egozi et al, 2014; Legewie and DiPrete, 2014b) uses direct, detailed measures of person characteristics to model the choice of a college major. Under this strategy, major characteristics, however, remain unobserved and therefore are only modelled indirectly through variables such as STEM/non-STEM or proportion female. Hence, the matching process in part can only be assumed to operate by the mechanisms suggested by theory.

A second set of studies follows the reverse strategy and applies direct measures of major characteristics as determinants of women's and men's choices but in turn does not measure the substantively relevant individual characteristics (Xie and Shauman, 1997; Shauman, 2006; 2009; Beffy et al. 2012). Because the individual characteristics remain unobserved, the matching process, again, can only be modelled in part and must therefore partially be assumed to be driven by the mechanisms in question.

We here combine these two approaches and model the sorting of individuals into majors as a match of persons with specific, directly measured characteristics (e.g. relative strength in math) to majors with corresponding characteristics (e.g. math intensity) which are measured as well. Observing both individual and major characteristics then allows us to model their matches as the generative mechanisms put forward by the competing theories and thus pursue a more rigorous approach to identification of the effects of interest (Knight and Winship, 
2013). To this end, we fit conditional logit models of the following form to our data (McFadden, 1974):

$$
p_{i k}=\frac{\exp \left(\mathbf{X}_{i k} \beta\right)}{\sum_{j=1}^{J} \exp \left(\mathbf{X}_{i j} \beta\right)}
$$

Where $p_{i k}$ is the probability for person $i$ to choose major $k, J$ is the number of majors in the choice set, and $\boldsymbol{X}_{i j}$ is a vector of independent variables. The distinguishing feature of the conditional logit model is that it allows $\boldsymbol{X}_{i j}$ to take on values specific to every single combination of person $i$ with major $j$ and thereby enables us to model the fact that when a person chooses from a set of majors, the outcome of that choice depends on the match between specific person characteristics with the corresponding features of all majors - the one chosen as well as those not chosen. ${ }^{\text {vi }}$

As a preliminary analysis, we assess whether the various individual attributes indeed influence major choices in the ways suggested by theory (table 3). The decomposition analysis that follows (table 4) is at the heart of our analysis because it serves to assess the relative explanatory power of the various theories in question. As a starting point for the decomposition, we translate sex segregation as a macro outcome into the individualistic choice perspective that is inherent to the conditional logit (i.e. discrete choice) model. This is achieved through a variable (femalexpropfemale) that interacts a person's gender (female/male) with the sex composition of a major (proportion female). In a model without further independent variables (the 'baseline model'), the coefficient of this variable reflects women's higher propensity to choose such majors that other women also disproportionately choose as well as men's higher propensity to choose majors that other men also disproportionately choose (if $\mathrm{OR}>1$ ). Absent this association (if $\mathrm{OR}=1$ ), women and men would distribute themselves proportionally across majors, and there would be no sex segregation.

The decomposition is, in essence, a mediation analysis in which we condition on the various hypothesized causal mechanisms by adding the corresponding sets of variables to the baseline model to observe how much the coefficient for femalexpropfemale diminishes. A large reduction of the coefficient for femalexpropfemale implies that the added set of variables mediates a large part of sex segregation. Because our variables lack an inherent causal order that could guide the order of their sequential inclusion into the model, we also 
obtain lower bounds for the explanatory power of variables by dropping them from a full model (Shauman, 2006; Morgan et al., 2013). ${ }^{\text {vii }}$ All models, including the baseline model, also include 22 dummy variables, one for each major in the choice set (and economic sciences as the reference category) to hold the marginal distribution constant, i.e. to account for the fact that certain majors happen to generally attract more students than other fields. Because we are not interested in major choice per se, but only in choices that segregate women from men, these main effects are substantially irrelevant and therefore not reported (Shauman, 2006). ${ }^{\text {viii }}$

\section{Results}

\subsection{Descriptive results}

The descriptive statistics reveal the explanandum of our study: a substantial degree of sex segregation in college majors (figure 1, also see table A10). No less than 40 percent of females would have to switch their major if all disciplines were to become fully integrated.

Our bivariate statistics lend preliminary plausibility to essentialism theory in both its preference- and constraint-based variants. Majors differ considerably in the degree to which they demand mathematical skills and women are clearly underrepresented in the more mathintensive disciplines (figure 2, table 1). Women in our sample also have slightly lower math grades than men (table 2). Men, in turn, have substantially worse average grades in German literature than women, so that their relative advantage tends to be in mathematics whereas for women it tends to be in German literature (table 2). Consonant with the preference-based essentialism argument, we see clear cut gender differences in vocational interests: Men report much higher interest in practical tasks (e.g. 'realistic') and somewhat higher interest in analytical ones (e.g. 'investigative'); women indicate substantially higher interest in 'social' and 'artistic' activities than their male counterparts whereas interest in 'enterprising' or 'conventional' tasks is similarly distributed among women and men (table 2).

Gender norms, as we operationalized them, are also broadly in line with the theoretically derived prediction that women receive more approval than men in fields that are femaletypical and vice versa (table 1). The degree of approval individuals receive from friends for choosing a particular field, however, appears to depend more heavily on a person's gender than the degree of approval individuals receive from parents (figures 3 and 4, table 1). In particular, women receive significantly less approval from friends than men when they opt for electrical engineering, computer science, or mechanical engineering. Men, in turn, receive 
less support from friends if they choose to study social work, philologies/cultural studies, or get on the track to become a pedagogue or school teacher. Note, however, that these measures are plagued with a substantial degree of uncertainty as indicated by large standard errors (table A7).

Our descriptive statistics do not support the separate spheres conjecture. First, women do not value pleasant working hours significantly more than men do (table 2) and over work norms (as well as subjective dissatisfaction with these) do not vary much across college majors (figure 6). Only doctors' work norms clearly exceed the average (and doctors report much higher dissatisfaction with these norms) but women are nevertheless proportionally represented in the track that leads into this particularly taxing profession (table A6). Second, women do not value 'good remuneration' less than men do (table 3) although they typically end up choosing less lucrative fields (table 1, figure 6).

Furthermore, we see considerable variation across majors in the extent to which women report that not having "the 'right' gender" matters when looking for a job (figure 7, table A7). Perceived discrimination against women is lowest among teachers who enter German public service through a highly formalized, grade-based procedure and is highest in the maledominated field of mechanical engineering and among doctors. Overall, our measure for discrimination against women is negatively correlated with the proportion of women in a discipline, as we would expect from theory (table 1). 
Figure 1: Proportion female across college majors.

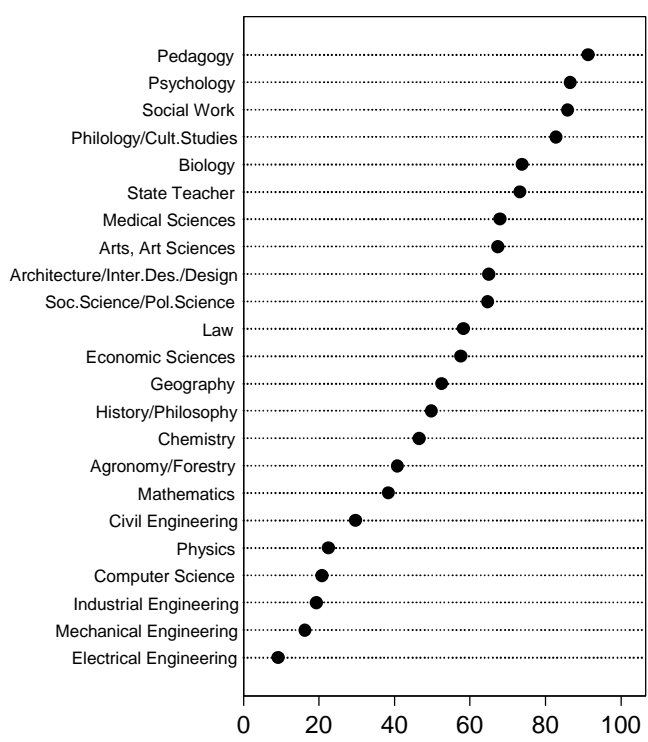

Sources: NEPS-SC5.

Figure 2: College majors, sorted by the math intensity of their curriculum.

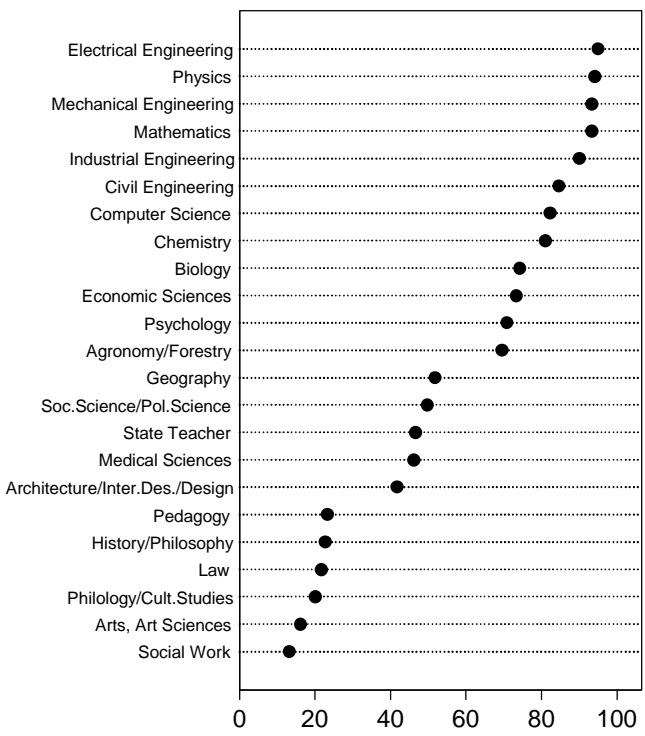

Source: NEPS-SC5
Figure 3: Rates of approval from parents for major choice, sorted by gender bias.

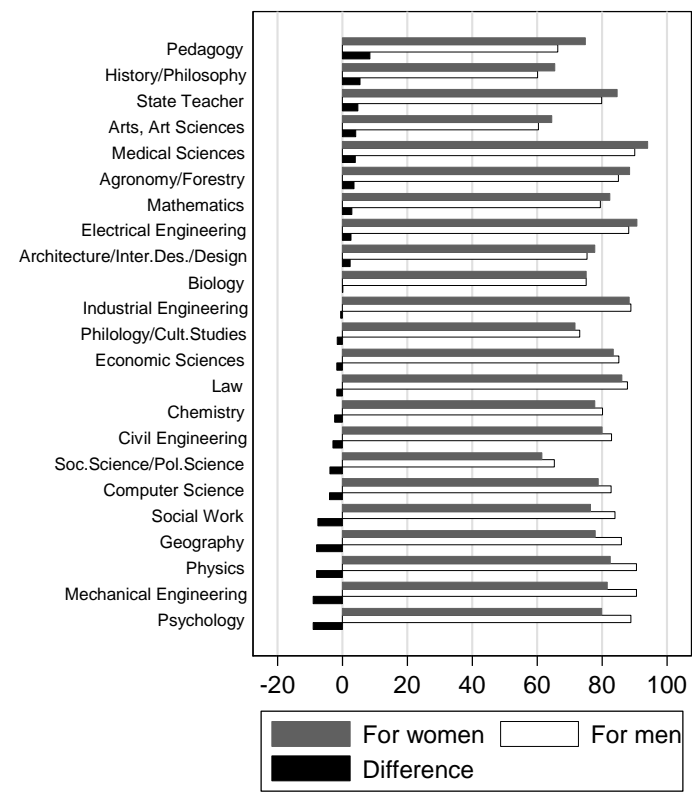

Source: NEPS-SC5

Figure 4: Rates of approval from friends for major choice, sorted by gender

bias.

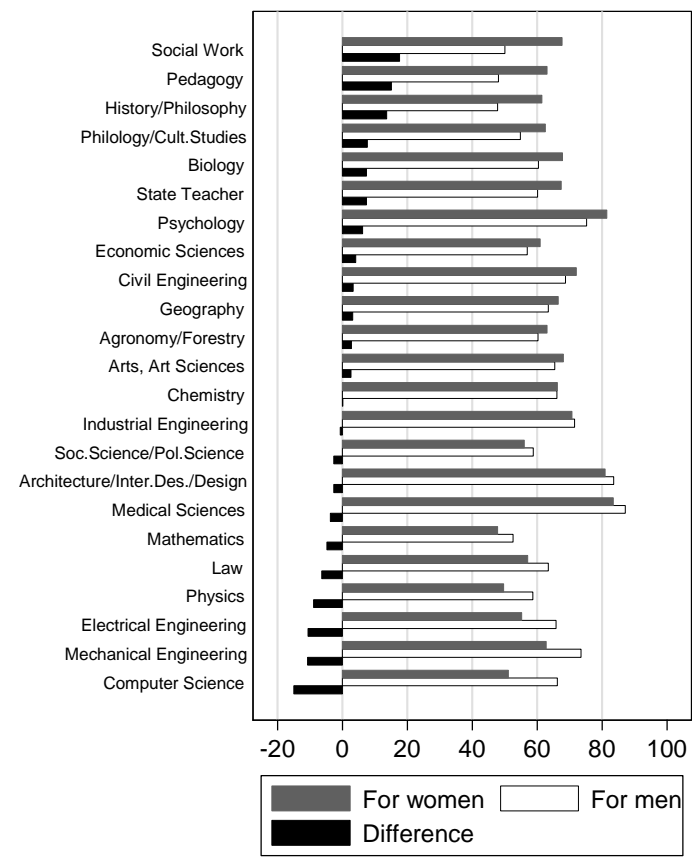

Source: NEPS-SC5. 
Figure 5: Hours worked and personal dissatisfaction with work-life issues across college

majors.

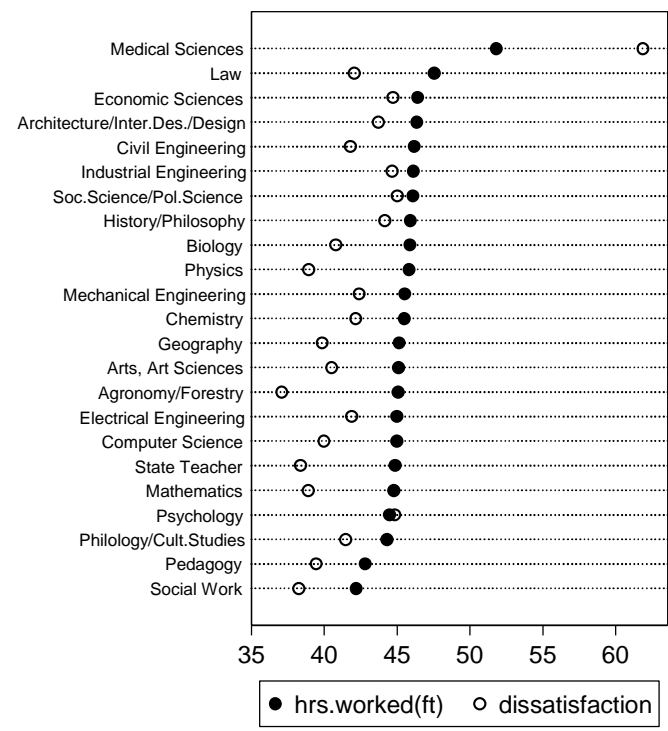

Source: Micro Census, HIS graduate panel studies.

Figure 6: Wage levels across college majors (percentage difference relative to economic sciences).

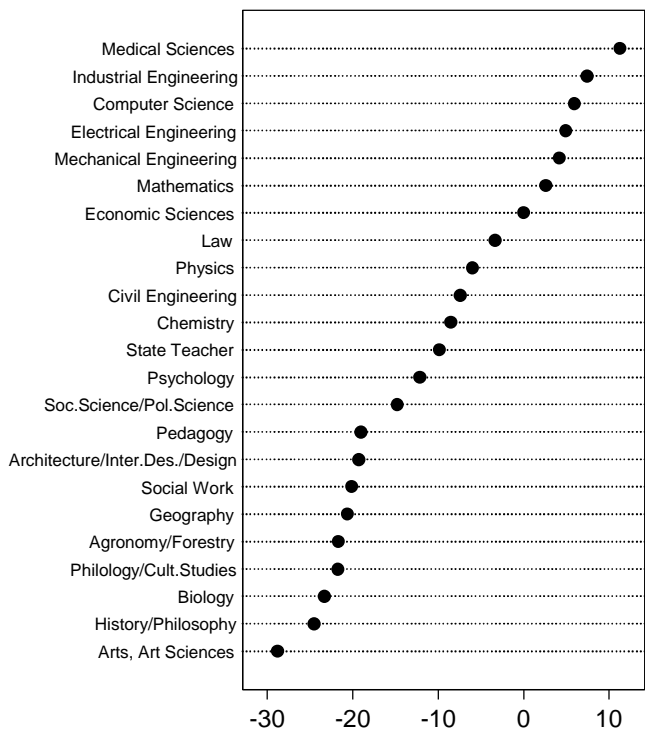

Source: Micro Census.
Figure 7: Perceived discrimination against women across college majors.

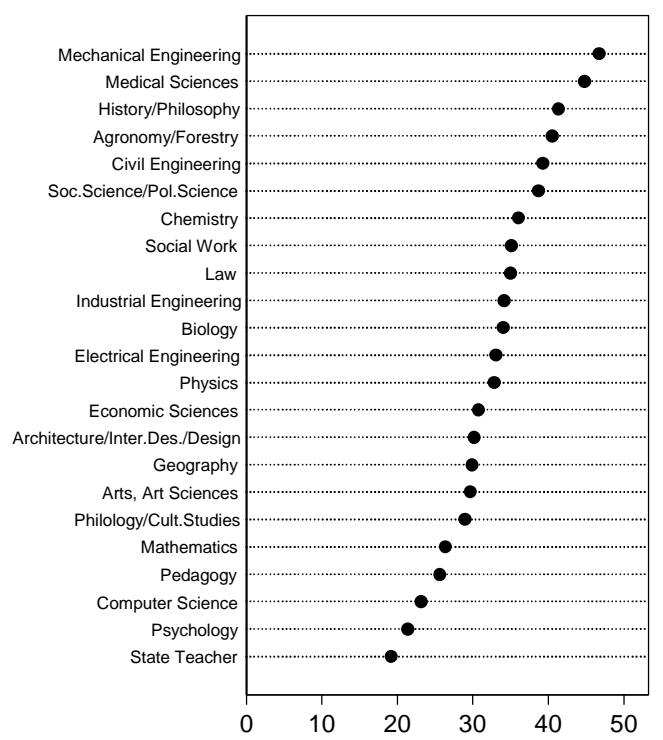

Source: HIS graduate panel studies. 
Table 1: Correlation matrix for major characteristics.

\begin{tabular}{|c|c|c|c|c|c|c|c|c|}
\hline & $\begin{array}{l}\text { Proportion } \\
\text { female }\end{array}$ & $\begin{array}{l}\text { Wage } \\
\text { level }\end{array}$ & $\begin{array}{c}\text { Math } \\
\text { intensity }\end{array}$ & Care & $\begin{array}{c}\text { Female } \\
\text { gender norm } \\
\text { (parents) }\end{array}$ & $\begin{array}{c}\text { Female } \\
\text { gender norm } \\
\text { (friends) }\end{array}$ & $\begin{array}{c}\text { Overwork } \\
\text { norm }\end{array}$ & $\begin{array}{l}\text { Discrimination } \\
\text { against } \\
\text { women }\end{array}$ \\
\hline Proportion female & 1.00 & - & - & - & - & - & - & - \\
\hline Wage level & -0.59 & 1.00 & - & - & - & - & - & - \\
\hline Math intensity & -0.75 & 0.62 & 1.00 & - & - & - & - & - \\
\hline $\begin{array}{l}\text { Care } \\
\text { Female gender norm }\end{array}$ & 0.61 & -0.01 & -0.35 & 1.00 & - & - & - & - \\
\hline $\begin{array}{l}\text { (parents) } \\
\text { Female gender norm }\end{array}$ & 0.18 & -0.14 & -0.31 & 0.12 & 1.00 & - & - & - \\
\hline (friends) & 0.73 & -0.68 & -0.60 & 0.47 & 0.24 & 1.00 & - & - \\
\hline Overwork norm & -0.16 & 0.45 & 0.11 & -0.10 & 0.13 & -0.41 & 1.00 & - \\
\hline Discrim. against women & -0.32 & 0.12 & 0.07 & -0.28 & -0.08 & -0.13 & 0.48 & 1.00 \\
\hline
\end{tabular}

Notes: Weighted estimates; sources: Micro Census 2007, 2008, 2009; HIS graduate panel studies 1997, 2001 ; NEPS-SC5. 
Table 2: Individual characteristics by gender.

\begin{tabular}{|c|c|c|c|c|c|c|}
\hline & \multicolumn{2}{|c|}{ females } & \multicolumn{2}{|c|}{ males } & \multirow[b]{2}{*}{ diff. } & \multirow[b]{2}{*}{ Wald test } \\
\hline & mean & s.e. & mean & s.e. & & \\
\hline \multicolumn{7}{|l|}{ Vocational interests } \\
\hline Realistic $[0 ; 1]$ & .39 & .003 & .53 & .005 & -.15 & .000 \\
\hline Investigative $[0 ; 1]$ & .50 & .004 & .56 & .004 & -.06 & .000 \\
\hline Artistic $[0 ; 1]$ & .68 & .004 & .54 & .004 & .14 & .000 \\
\hline Social $[0 ; 1]$ & .54 & .004 & .36 & .004 & .18 & .000 \\
\hline Enterprising $[0 ; 1]$ & .59 & .003 & .59 & .004 & .00 & .991 \\
\hline Conventional $[0 ; 1]$ & .43 & .003 & .41 & .004 & .03 & .000 \\
\hline \multicolumn{7}{|l|}{ Educational preparation } \\
\hline Math grade $[0 ; 15]$ & 10.09 & .050 & 10.33 & .061 & -.24 & .003 \\
\hline German grade $[0 ; 15]$ & 10.86 & .037 & 9.64 & .048 & 1.23 & .000 \\
\hline Rel. math grade (math grade - German lit. grade) & -.77 & .053 & .69 & .066 & -1.46 & .000 \\
\hline \multicolumn{7}{|l|}{ Job values } \\
\hline (a) Pleasant working hours & .70 & .003 & .68 & .005 & .02 & .000 \\
\hline (b) Good remuneration & .71 & .003 & .72 & .004 & -.01 & .016 \\
\hline $\mathrm{N}$ & \multicolumn{2}{|c|}{5,795} & \multicolumn{2}{|c|}{3,314} & & \\
\hline
\end{tabular}

Notes: Weighted estimates; Source: NEPS-SC5. 


\subsection{Multivariate results}

Inspection of the parameter estimates from a first conditional logit model (table 3) allows us to scrutinize if person characteristics indeed affect college major selection in the ways assumed by the various theories we reviewed above. Our findings almost unanimously confirm the behavioral assumptions of the theories. With regards to gender essentialism, we find that persons with 'realistic' interests are substantially more inclined to take up mathintensive majors. Net of other influences, each additional percentage point in a major's math rating is associated with an increase in the odds for choosing this major which is seven percent larger for persons who are very interested in realistic tasks compared with persons who are uninterested in realistic tasks. High 'investigative' interests similarly motivate students to choose math-intensive majors, whereas respondents whose interests fall on the 'artistic' side tend to eschew such fields. Persons with a strong interest in 'social' vocational tasks gravitate towards care-related majors and avoid math-intensive disciplines net of other influences. As expected, persons with better math than German literature grades are more likely to select math-intensive majors than those with a relative disadvantage in math.

We also see that respondents are inclined to choose fields where they can expect to receive more approval from friends than their counterparts of the other sex. College entrants' choices are, however, not consonant with regards to the (significantly less pronounced) gender norms set by parents.

The results from this model support two foundations of the separate spheres conjecture: The more a person values "earning well" in a vocational activity (ceteris paribus), the more likely she is to select into college majors that yield high wages in the labor market. Persons with a stronger preference for "pleasant working hours" indeed eschew fields that would impose a higher time strain on their private lives in the future.

The findings reported in table 3 are also in line with the anticipated discrimination hypothesis. Net of other factors, women appear to avoid training for professions where higher proportions of women of a previous cohort reported to be disadvantaged due to sex-based discrimination.

Up to this point, we have scrutinized the various premises of the competing theoretical explanations. The fact that we found most of the theories' underlying assumptions to hold true underlines the necessity to next assess their relative explanatory power for horizontal sex segregation. To this end, table 4 presents the decomposition results, beginning with the 
baseline model in which the explanandum of this study is merely re-expressed in the terms of a conditional logit model: women tend to sort into majors where their fellow students are mostly females and men flock into disciplines where they are disproportionately surrounded by other men: Without conditioning on the various theoretically relevant mechanisms, each additional percentage point in proportion female is associated with an increase in women's odds for choosing such major that is 4.5 percent larger than men's.

Table 4 summarizes the results of our decomposition of this absolute level of sex segregation into its various components. The first thing to note is that all theories combined only amount to moderate total explanatory power. Although we account for a broad range of potential explanations, the variables in our models explain only half (46 percent) of the differences in women's and men's choices. Taken together, the different variants of the gender essentialism hypothesis wield virtually all of the analytical power as they explain 45.8 percent of horizontal sex segregation. Most of this share is due to gendered vocational interests (36.5 to 37.2 percent) in social, artistic, and practical (i.e. 'realistic') tasks. The fact that women and men face different incentive structures with regards to social approval from peers and parents picks up a much smaller share of sex segregation (3.6 to 7.5 percent). This implies that the failure of previous studies to specify social norms does not invalidate their interpretation along the lines of preference-based essentialism theory. Our results suggest that essentialism indeed segregates women and men mostly through internalization. Consistent with previous studies (Xie and Shauman, 2003; Hyde et al., 2008; Riegle-Crumb et al., 2012; Mann and DiPrete, 2013; Morgan et al. 2013), gender differences in academic performance almost entirely fail to explain differences in major choices.

The separate spheres argument, according to which women purposely avoid professional labor markets where working extra hours is common and care less for high wages than men, has no explanatory power at all in our analysis of horizontal differences. The same is true for the anticipated discrimination conjecture.

In a mediation analysis such as the one we conduct here, good measures for a mediating mechanism generally allow for more covariance to travel from cause to effect than poor measures do. Thus, the stronger empirical support for the gender essentialism perspective may be due to a better operationalization with more, possibly better measures compared with the separate spheres argument. To check whether this is case, we repeated our analysis with a much broader set of variables to reflect the separate spheres conjecture. We additionally considered the possibility that men value "good chances to move up in the career ladder" 
more highly in a job than women and therefore select more lucrative majors. Based on later waves of NEPS-SC5, we also considered whether persons choose majors with different wage levels because they think that "the man's job is to earn money; the woman's job is to take care of the household and family", as well as whether men and women choose majors with different work norms because they think that men and women should have different duties in the household. Despite this considerably broader set of measures, the separate spheres conjecture continues to fail at explaining any of the gender differences that are not already accounted for by the competing explanations and even under the most favorable assumption about the causal ordering of effects explains at most 5 percent of gender differences in major choices (tables A8 and A9). ${ }^{\text {ix }}$

In sum, the preference-based variant of essentialism theory proves to be the strongest explanation for sex segregation as suggested by previous studies. Our results confirm that this remains true even when one accounts for normative constraints exerted by parents and peers, anticipation of gendered family roles, and anticipation of sex-based discrimination. 
Table 3: Determinants of college major choice, parameters from a conditional logit model.

Person characteristic. $\mathrm{x}$ major char.

Odds ratio

Odds ratio

(semi-std.)

\section{Gender Essentialism}

Preferences: vocational interests

Realistic $x$ math intensity

$\begin{array}{cc}1.070^{\star \star *} & 1.576^{\star \star *} \\ (.0040) & (.0394) \\ .996^{*} & 0.965^{\star} \\ (.0017) & (.0162) \\ & \\ 1.063^{\star * *} & 1.494^{\star * *} \\ (.0035) & (.0327) \\ 1.011^{\star * *} & 1.111^{\star * *} \\ (.0015) & (.0162)\end{array}$

Artistic $x$ math intensity

$.946^{* * *}$

$(.0031)$

Artistic $\mathrm{x}$ care

$0.997^{*}$

$.670^{* * *}$

(.0014)

$(.0157)$

$0.964^{*}$

(.0141)

Social $x$ math intensity

$.964^{* * *}$

$.789^{* * *}$

Social $x$ care

$(.0035)$

$1.058^{\star \star \star}$

(.0186)

(.0019)

$1.697^{* \star \star}$

Enterprising $\mathrm{x}$ math intensity

$.993^{*}$

(.0289)

Enterprising $\mathrm{x}$ care

(.0038)

$.992^{* * *}$

(.0017)

$.959^{*}$

(.0202)

$.937^{\star * *}$

(.0131)

Conventional $\mathrm{x}$ math intensity

.996

(.0036)

.998

Conventional $\mathrm{x}$ care

(.0017)

.980

(.0197)

.983

(.0134)

Abilities: educational preparation

Rel. math grade $x$ math intensity

$1.003^{* * *} \quad 1.288^{* * *}$

(.0002)

(.0267)

Constraints: social norms

Female $x$ diff. parents' approval

$.977^{\star *}$

$.942^{* *}$

(.0075)

Female $\mathrm{x}$ diff. friends' approval

$1.064^{\star * *}$

(.0183)

(.0055)

(.0282)

Separate spheres

Preferences

Earning well $\mathrm{x}$ wage level

$1.058^{* * *}$

$1.143^{\star * *}$

(.0076)

(.0195)

Constraints

Pleasant work hrs. $\mathrm{x}$ overwork norms

$\begin{array}{ll}.865^{\star \star *} & .945^{\star \star *} \\ (.0294) & (.0125)\end{array}$

Anticipated discrimination

$.986^{* * *} \quad .953^{* * *}$

(.0039)

(.0135)

Major fixed-effects

Yes

Yes

$\mathrm{N}=$

9,109

9,109

$\mathrm{J}=$

23

23

Notes: Weighted estimates, standard errors in parentheses, ${ }^{*} \mathrm{p}<.05,{ }^{* *} \mathrm{p}<.01,{ }^{* * *}<.001$; right column reports coefficients for standardized independent variables; Sources: NEPS-SC5, Micro Census, HIS graduate panel studies. 
Table 4: Explanatory power of variables and variable groups for sex segregation in college majors, decomposition results from a mediation analysis on the basis of conditional logit models.

\begin{tabular}{|c|c|c|c|c|}
\hline & \multicolumn{2}{|c|}{$\begin{array}{l}\text { When adding term } \\
\text { to baseline model }\end{array}$} & \multicolumn{2}{|c|}{$\begin{array}{l}\text { When removing term } \\
\text { from full model }\end{array}$} \\
\hline & $\begin{array}{l}\text { OR for female } \\
x \text { prop.female }\end{array}$ & $\begin{array}{l}\text { Percentage } \\
\text { explained }\end{array}$ & $\begin{array}{l}\text { OR for female } \\
x \text { prop.female }\end{array}$ & $\begin{array}{l}\text { Percentage } \\
\text { explained }\end{array}$ \\
\hline Baseline model & 1.0452 & 0 & - & - \\
\hline Full model (all variables) & 1.0244 & 46.0 & - & - \\
\hline Essentialism (total) & 1.0245 & 45.8 & 1.0451 & 45.8 \\
\hline Preferences: vocational interests (total) & 1.0284 & 37.2 & 1.0409 & 36.5 \\
\hline Realistic $\times$ [math intensity, care] & 1.0401 & 11.3 & 1.0308 & 14.2 \\
\hline Investigative [math intensity, care] & 1.0442 & 2.4 & 1.0253 & 2.2 \\
\hline Artistic $\mathrm{x}$ [math intensity, care] & 1.0398 & 12.0 & 1.0300 & 12.4 \\
\hline Social x [math intensity, care] & 1.0398 & 12.1 & 1.0293 & 10.8 \\
\hline Enterprising $\mathrm{x}$ [math intensity, care] & 1.0459 & -1.5 & 1.0242 & -0.5 \\
\hline Conventional x [math intensity, care] & 1.0457 & -1.0 & 1.0242 & -0.3 \\
\hline \multicolumn{5}{|l|}{ Abilities: educational preparation (total) } \\
\hline Rel. math grade $x$ math intensity & 1.0428 & 5.4 & 1.0246 & 0.4 \\
\hline Constraints: social norms (total) & 1.0436 & 3.6 & 1.0278 & 7.5 \\
\hline Female $x$ diff. parents' approval & 1.0454 & -0.5 & 1.0239 & -1.0 \\
\hline Female $x$ diff. friends' approval & 1.0434 & 4.1 & 1.0289 & 10.1 \\
\hline $\begin{array}{l}\text { Separate spheres (total) } \\
\text { Preferences }\end{array}$ & 1.0453 & -0.1 & 1.0239 & -1.1 \\
\hline $\begin{array}{l}\text { Earning well } \mathrm{x} \text { wage level } \\
\text { Constraints }\end{array}$ & 1.0452 & 0.0 & 1.0241 & -0.7 \\
\hline Pleasant work hrs. x overwork norms & 1.0452 & 0.0 & 1.0241 & -0.7 \\
\hline \multicolumn{5}{|l|}{ Anticipated discrimination } \\
\hline Female $\mathrm{x}$ discrimination & 1.0449 & 0.7 & 1.0249 & 1.2 \\
\hline
\end{tabular}




\section{Limitations and two calls for replication}

Although we believe that with this finding our study contributes significantly to the state of research, we want to point out that in the data we used, vocational interests were measured at the very beginning of college study when majors were already declared. This implies that in the presence of post-hoc rationalization, stated interests could be endogenous to the choice of a major. We will now discuss how this might impact our results.

The directed acyclic graph in figure 8a illustrates our conception of the effect of gender on choosing a predominantly female college major as mediated by vocational interests: A person's gender $(X)$ causes the development of certain interests at $t_{0}\left(I_{t 0}\right)$, where $t_{0}$ is a point in time briefly before a major is declared; $\mathrm{I}_{\mathrm{t} 0}$ (e.g. 'investigative interests') then has a causal effect on $J$, the choice of a major with a specific major characteristic that matches the interest $\mathrm{I}_{\mathrm{t} 0}$ (e.g. 'math intensity'). $\mathrm{J}$ in turn effects whether a person finds herself studying a predominantly female college major (Y).

Because NEPS-SC5 starts surveying students at the beginning of their first college semester $\left(t_{1}\right)$, not beforehands, we cannot directly condition on $I_{t 0}$. However, under the assumption that $\mathrm{I}_{\mathrm{t} 0}$ strongly predicts $\mathrm{I}_{\mathrm{t} 1}$, we can condition on $\mathrm{I}_{\mathrm{t} 0}$ by conditioning on $\mathrm{I}_{\mathrm{t} 1}$ (Knight and Winship, 2013). This strategy is valid under the assumption that the causal effect of $X$ on $I_{t 1}$ (which runs through $I_{t 0}$ ) so clearly predominates over the effect of $J$ on $I_{t 1}$ that the effect of $\mathrm{J}$ on $\mathrm{I}_{\mathrm{t} 1}$ can be considered negligible (figure 8a). This is another way of saying that for our strategy to be successful, we must subscribe to the assumption that most of the gender differences in vocational interests develop already in high school, and not in the period between the designation of a major and the first survey in the first semester in college. ${ }^{\mathrm{x}} \mathrm{A}$ large body of research supports this assumption: Lapan et al. (1996) surveyed 101 persons on their aspirations and interests before they entered college and again 3.5 years later to conclude that "aspirations for entering a math/science major had solidified before the students in our sample began attending college" (Ibid.: 288) and that "the decision to enter a math/science major was in large part a function of preexisting efficacy and vocational interest patterns." (Ibid.) Based on a meta-analysis of 108 interest studies that were conducted mostly on young people, Su et al. (2009) report that (net of cohort effects) gender differences are larger in young years than later in life. In a retrospect of 35 years of research on the subject, Eccles (2007) also concludes that gender differences in the value placed on science and engineering related vocations start to build up early in life, long before the transition from high school to college. Reviewing the state of research, Low and Rounds (2007) compare the stability of 
vocational interests across young persons' lives and show that stability increases markedly from the age of 16 onwards and throughout the college years, whereas if people were postrationalizing the college major choices they made for other reasons, the college years would have to be a period of interest adaptation and hence instability. On the basis of a review of 256 longitudinal studies, Low (2009) reports that men's realistic interests remain stable during the college years, whereas women's increase somewhat and investigative, artistic, and social interests grow in patterns that are very similar for women and men. He also concludes that men's interest in mathematics increases during the high school years whereas women's does not, and that the reverse is true during the college years (Ibid.: 58). All of these findings are at odds with the notion that gender differences in vocational interests arise after graduation from high school, as post-hoc rationalizations of major selection which leads us to believe that $\mathrm{J} \rightarrow \mathrm{I}_{\mathrm{t} 1}$ can indeed be assumed negligible relative to $\mathrm{X} \rightarrow \mathrm{I}_{\mathrm{t} 0} \rightarrow \mathrm{I}_{\mathrm{t} 1}$.

Nevertheless, this remains an assumption we cannot test here. If the effect of $Y$ on $I_{t 1}$ was non-negligible, then $I_{t 1}$ is a collider that, when conditioned on, opens the path $X \rightarrow I_{t 0} \rightarrow I_{t 1}$ $\leftarrow \mathrm{J} \rightarrow \mathrm{Y}$ (figure 8b, Elwert and Winship, 2014). Measuring RIASEC scores prior to major choice would therefore be preferable to the strategy we here pursue. In the coming years, two developments will also make this option viable:

First, due to the multi-cohort nature of NEPS, data from respondents who entered NEPS as 9th graders will become suitable panel data with information on vocational interests recorded prior to major choice once respondents enter college and designate a major (Wagner et al., 2011). Second, the HIS college eligible panel 2009/10 surveyed pupils about their vocational interests before graduation in 2009/10 and again half a year after graduation when a subset of respondents had designated their college major (Lörz et al., 2012). The data of both panel waves are likely to become available to the scientific community in the next few years (Wissenschaftsrat, 2014). To facilitate these replications and thereby the scrutiny of our non-collider assumption, we have deposited a replication package at Social Science Research and the Harvard Dataverse (Ochsenfeld, 2015) and encourage researchers to make good use of it. 
Figure 8: Directed acyclic graphs to illustrate the non-collider assumption (a) and its potential failure (b).

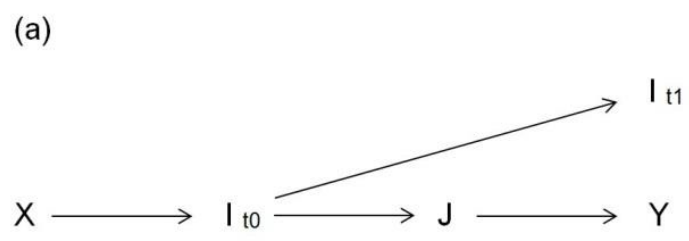

(b)

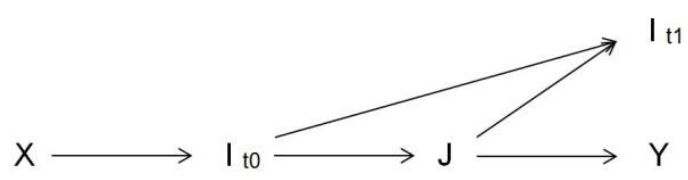

\section{Conclusion}

In this article, we have analyzed gender differences in college major selection for participants in NEPS-SC5, a large, nationally representative sample of individuals who entered college in Germany in fall 2010. Theoretically, our analysis departed from a dissatisfaction with explanations that are based on differences in expectations or plans. We argued that such explanations beg the question why women and men expect to work in different occupations later in life and, more specifically, offer little insight into whether women want to take up different subjects than men or whether they have to do so in order to avoid constraints men do not face to the same degree. To address this shortcoming of previous works, we conducted a choice analysis that explicitly models three hitherto understudied constraints that women could anticipate when making the transition from school to college.

First, we scrutinized the possibility that women and men must expect to receive systematically different rates of approval from their parents and peers for certain sex-typed majors and adapt their behavior to these incentives. We found that for certain majors social approval rates indeed differ substantively by gender, in particular with regards to approval from friends. Our decomposition analysis revealed, however, that the explanatory power of such differences for horizontal segregation is small - a hithereto untested assumption that underlies nearly all essentialist interpretations. 
Second, we tested for the possibility that women, already at the time of entering college, foresee the looming time conflict between the mother and the worker role which they might attempt to mitigate, choosing majors so to steer away from labor market segments with burdensome overwork cultures. Our empirical analyses, however, produced no evidence whatsoever for this claim.

Third, answering Mann and DiPrete's call (2013: 1532), we scrutinized the possibility that certain segments of the labor market are perceived as or indeed are more hostile towards females than others so that women eschew professions where they must expect to face discrimination. Empirically, we found such behavior to be too weak to explain gender differences in major selection. With data from Germany, we here also corroborated the finding from US-based studies that differences in life goals or academic performance have little to offer for an explanation of sex segregation in college.

In sum, theories that conceive of major choices as resulting from the anticipation of a future that still lies a few years away receive no support from our analysis. Our results instead suggest that the high degree of sex segregation in college is rooted in the highly presentist fashion in which young individuals appear to choose between majors: They mostly seem to act on the vocational interests they hold at the time of entering college and - to a much lesser extent - respond to expectations in their peer group. Because both vocational interests and friends' expectations are highly gendered, the choices made by college entrants are, too. This picture is perfectly consonant with the claim that an essentialist gender culture conspires with liberal individualism to bring about a high degree of sex segregation in higher education and, later on, the labor market, too (Charles and Bradley, 2002, 2009; Grusky and Levanon, 2008). Furthermore, and adding to previous research (Legewie and DiPrete, 2014a), our study suggests that in order to equalize the distribution of women and men across majors, interventions directed at adolescents' experiences during high school, when gender-specific substantive preferences are shaped and traditionalist peer norms form, are the most promising.

The decisions we studied here are extreme cases of high-cost situations. Few persons will get to make many more decisions that are equally financially consequential as is the choice whether to major in performing arts or in engineering instead. Despite this fact, our results suggest that gender differences in occupational choice are mostly due to differences in preferences. Our study is thus consonant with recent calls for understanding educational choices as expressive assertions of identity, and not solely as instances of instrumental action (Charles and Bradley, 2009; Frye, 2012; Cech, 2014). 


\section{Acknowledgments}

Earlier versions of this article were presented at the 2014 ECSR Conference, the 2015 Spring Meeting of the Research Committee on Social Stratification and Mobility (RC28) of the ISA, and at seminars at the University of Munich and at Goethe University. I thank all participants at those presentations as well as Carlotta Giustozzi, Daniela Grunow, Jonathan Latner, Kristina Lindemann, Anne Kronberg, and two anonymous reviewers for helpful comments and Markus Gangl for bringing my attention to the conditional logit model. This paper uses data from the National Educational Panel Study (NEPS): Starting Cohort First-Year Students, doi:10.5157/NEPS:SC5:4.0.0. From 2008 to 2013, NEPS data was collected as part of the Framework Program for the Promotion of Empirical Educational Research funded by the German Federal Ministry of Education and Research (BMBF). As of 2014, NEPS is carried out by the Leibniz Institute for Educational Trajectories (LIfBi) at the University of Bamberg in cooperation with a nationwide network. The HIS Graduate Panel data have kindly been provided by GESIS, Cologne, the census data by the Federal Statistical Office, Wiesbaden. 


\section{References}

Andreß, H.-J., Hagenaars, J., \& Kühnel, S. (1997). Analyse von Tabellen und kategorialen Daten. Log-lineare Modelle, latente Klassenanalyse, logistische Regression und GSK-Ansatz. Berlin: Springer.

Arcidiacono, P., Hotz, V. J., \& Kang, S. (2012). Modeling college major choices using elicited measures of expectations and counterfactuals. Journal of Econometrics, 166, 3-16.

Aßmann, C., Steinhauer, H. W., Kiesl, H., Koch, S., Schönberger, B., Müller-Kuller, A., Rohwer, G., Rässler, S., \& Blossfeld, H.-P. (2011). Sampling designs of the National Educational Panel Study: Challenges and Solutions. Zeitschrift für Erziehungswissenschaft, 14, 51-65.

Baker, D., \& Entwisle, D. (1987). The Influence of Mothers on the Academic Expectations of Young Children: A Longitudinal Study of How Gender Differences Arise. Social Forces, 65, 670-694.

Barone, C. (2011). Some Things Never Change. Gender Segregation in Higher Education across Eight Nations and Three Decades. Sociology of Education, 84, 157-176.

Becker, G. (1957). The Economics of Discrimination. Chicago: The University of Chicago Press.

Becker, G. (1975). Human Capital. A Theoretical and Empirical Analysis with Special Reference to Education. Chicago: The University of Chicago Press.

Beffy, M., Fougère, D., \& Maurel, A. (2012). Choosing the Field of Study in Postsecondary Education: Do Expected Earnings Matter? The Review of Economics and Statistics, 94, 334347.

Bertrand, M., Goldin, C., \& Katz, L. (2010). Dynamics of the Gender Gap for Young Professionals in the Financial and Corporate Sectors. American Economic Journal: Applied Economics, 2, 228 255.

Best, H., \& Wolf, C. (2010). Logistische Regression. In H. Best \& C. Wolf (Eds.), Handbuch der sozialwissenschaftlichen Datenanalyse (pp. 827-854). Wiesbaden: VS.

Beutel, A. M., \& Marini, M. M. (1995). Gender and Values. American Sociological Review, 60, 436448.

Blake, J., \& Davis, K. (1964). Norms, Values, and Sanctions. In R. Faris (Ed.), Handbook of Sociology (pp. 456-484). Chicago: McNally.

Blau, F., Ferber, M., \& Winkler, A. (2010). The Economics of Women, Men, and Work (6 ed.). Upper Saddle River: Prentice Hall.

Blau, F., \& Kahn, L. (2007). The Gender Pay Gap: Have Women Gone as Far as They Can? Academy of Management Perspectives, 21, 7-23.

Blossfeld, H.-P., Roßbach, H.-G., \& von Maurice, J. (Eds.). (2011). Education as a Lifelong Process The German National Educational Panel Study (NEPS) (Vol. 14). Wiesbaden: VS.

Brennan, G., Eriksson, L., Goodin, R., \& Southwood, N. (2013). Explaining Norms. Oxford: Oxford UP.

Busch, A. (2013). Die Geschlechtersegregation beim Berufseinstieg - Berufswerte und ihr Erklärungsbeitrag für die geschlechtstypische Berufswahl. Berliner Journal für Soziologie, 23, 145-179.

Cech, E. (2014). The Self-Expressive Edge of Occupational Sex Segregation. American Journal of Sociology, 119, 747-789.

Cha, Y. (2013). Overwork and the Persistence of Gender Segregation in Occupations. Gender and Society, 27, 158-184.

Charles, M., \& Bradley, K. (2002). Equal but Seperate? A Cross-National Study of Sex Segregation in Higher Education. American Sociological Review, 67, 573-599.

Charles, M., \& Bradley, K. (2009). Indulging Our Gendered Selves? Sex Segregation by Field of Study in 44 Countries. American Journal of Sociology, 114, 924-976.

Charles, M., \& Grusky, D. B. (2004). Occupational Ghettos. The Worldwide Segregation of Women and Men: Stanford University Press.

Correll, S. J. (2001). Gender and the Career Choice Process. The Role of Biased Self-Assessments. American Journal of Sociology, 106, 1691-1730.

Cotter, D., Hermsen, J. M., \& Vanneman, R. (2011). The End of the Gender Revolution? Gender Role Attitudes from 1977 to 2008 . American Journal of Sociology, 117, 259-289. 
Davis, S., \& Greenstein, T. (2004). Cross-National Variations in the Division of Household Labor. Journal of Marriage and Family, 66, 1260-1271.

DiPrete, T., \& Buchmann, C. (2013). The Rise of Women. The Growing Gender Gap in Education and What It Means for American Schools. New York: Russell Sage Foundation.

Duffy, R. D., \& Sedlacek, W. E. (2007). What Is Most Important to Student's Long-Term Career Choices. Analyzing 10-Year Trends and Group Differences. Journal of Career Development, 34, 149-163.

Eccles, J. (2007). Where are all the women? Gender differences in participation in physical science and engineering. In S. Ceci \& W. Williams (Eds.), Why aren't more women in science? Top researchers debate the evidence (pp. 199-210). Washington, DC: American Psychological Association.

Eccles, J., Jacobs, J., \& Harold, R. (1990). Gender Role Stereotypes, Expectancy Effects, and Parents' Socialization of Gender Differences. Journal of Social Issues, 46, 183-201.

Elster, J. (1989). The cement of society. A study of social order. Cambridge: CUP.

Elwert, F., \& Winship, C. (2014). Endogeneous Selection Bias: The Problem of Conditioning on a Collider Variable. Annual Review of Sociology, 40, 31-53.

Fabian, G., \& Briedis, K. (2009). Aufgestiegen und erfolgreich. Ergebnisse der dritten HISAbsolventenbefragung des Jahrgangs 1997 zehn Jahre nach dem Examen. Hannover: HIS.

Fabian, G., \& Minks, K.-H. (2006). Dokumentation des Scientific Use Files "HIS Absolventenpanel 1997". Hannover: HIS.

Freeman, R. (1971). The Market for College-Trained Manpower. A Study in the Economics of Career Choice. Cambridge: HUP.

Frye, M. (2012). Bright Futures in Malawi's New Dawn: Educational Aspirations as Assertions of Identity. American Journal of Sociology, 117, 1565-1624.

Gabay-Egozi, L., Shavit, Y., \& Yaish, M. (2014). Gender Differences in Fields of Study: The Role of Significant Others and Rational Choice Motivations. European Sociological Review, forthcoming.

Gambetta, D. (1987). Were they pushed or did they jump? Individual decision mechanisms in education. Cambridge: CUP.

Gartner, H., \& Hinz, T. (2009). Geschlechtsspezifische Lohnungleichheit in Betrieben, Berufen und Jobzellen (1993-2006). Berliner Journal für Soziologie, 19, 557-575.

Gerber, T. P., \& Cheung, S. Y. (2008). Horizontal Stratification in Postsecondary Education. Forms, Explanations and Implications. Annual Review of Sociology, 34, 299-318.

Glass, J., \& Sassler, S. (2013). What's So Special about STEM? A Comparison of Women's Retention in STEM and Professional Occupations. Social Forces, 723-756.

Glocker, D., \& Strorck, J. (2014). Risks and returns to educational fields - A financial asset approach to vocational and academic education. Economics of Education Review, 42, 109-129.

Goldin, C. (2006). The Quiet Revolution That Transformed Women's Employment, Education, and Family. American Economic Review, 96, 1-22.

Goldin, C. (2014). A Grand Gender Convergence: Its Last Chapter. American Economic Review, 104, 1091-1119.

Goldin, C., \& Katz, L. (2011). The Cost of Workplace Flexibility for High-Powered Professionals. The Annals of the American Academy of Political and Social Science, 638, 45-67.

Goldin, C., \& Katz, L. (2012). The Most Egalitarian of All Professions: Pharmacy and the Evolution of a Family-Friendly Occupation. NBER Working Paper, 1840.

Grusky, D., \& Levanon, A. (2008). Four Gloomy Futures of Sex Segregation. In D. Grusky (Ed.), Social Stratification. Class, Race, and Gender in Sociological Perspective (pp. 812-825). Boulder: Westview.

Hakim, C. (2000). Work-Lifestyle Choices in the 21st Century. Preference Theory. Oxford/New York: Oxford UP.

Holland, J. (1985). Making vocational choices. A theory of vocational personalities and work environments (2nd ed.). Englewood Cliffs: Prentice-Hall.

Hyde, J., Lindberg, S., Linn, M., Ellis, A., \& Williams, C. (2008). Gender Similarities Characterize Math Performance. Science, 321, 494-495. 
Jacobs, J. A. (1989). Revolving Doors. Sex Segregation and Women's Careers. Stanford: SUP.

Jonsson, J. O. (1999). Explaining Sex Differences in Educational Choice. An Empirical Assessment of a Rational Choice Model. European Sociological Review, 15, 391-404.

Kerckhoff, A. (1976). The Status Attainment Process: Socialization or Allocation? Social Forces, 55, 368-381.

Knight, C., \& Winship, C. (2013). The Causal Implications of Mechanistic Thinking: Identification Using Directed Acyclical Graphs. In S. Morgan (Ed.), Handbook of Causal Analysis for Social Research (pp. 275-299). Dordrecht: Springer.

Lapan, R., Shaughnessy, P., \& Boggs, K. (1996). Efficacy Expectations and Vocational Interests as Mediators between Sex and Choice of Math/Science College Majors: A Longitudinal Study. Journal of Vocational Behavior, 48, 277-291.

Legewie, J., \& DiPrete, T. (2014a). The High School Environment and the Gender Gap in Science and Engineering. Sociology of Education, 87, 259-280.

Legewie, J., \& DiPrete, T. (2014b). Pathways to Science and Engineering Bachelor's Degrees for Men and Women. Sociological Science, 1, 41-48.

Lips, H. M. (2004). The Gender Gap in Possible Selves: Divergence of Academic Self-Views Among High School and University Students. Sex Roles, 50, 357-371.

Lörz, M., Schindler, S., \& Walter, J. (2011): Gender inequalities in higher education: extent, development and mechanisms of gender differences in enrolment and field of study choice. Irish Educational Studies, 30, 179-198.

Lörz, M., Quast, H., \& Woisch, A. (2012): Erwartungen, Entscheidungen und Bildungswege. Studienberechtigte 2010 ein halbes Jahr nach Schulabgang. Hannover: HIS.

Low, K.-S. (2009). Patterns of mean-level changes in vocational interests: a quantitative review of longitudinal studies. Dissertation: University of Illinois at Urbana-Champaign.

Low, K.-S., \& Rounds, J. (2007). Interest change and continuity from early adolescence to middle adulthood. International Journal for Educational and Vocational Guidance, 7, 23-36.

Ma, Y. (2011). Gender Differences in the Paths Leading to a STEM Baccalaureate. Social Science Quarterly, 92, 1169-1190.

Mann, A., \& DiPrete, T. (2013). Trends in gender segregation in the choice of science and engineering majors. Social Science Research, 42, 1519-1541.

Manski, C. F. (1993). Dynamic choice in social settings. Learning from the experiences of others. Journal of Econometrics, 58, 121-136.

McFadden, D. (1974). Conditional logit analysis of qualitative choice behavior. In P. Zarembka (Ed.), Frontiers in Econometrics. New York: Academic Press.

Montmarquette, C., Cannings, K., \& Mahseredjian, S. (2002). How do young people choose college majors? Economics of Education Review, 21, 543-556.

Morgan, L. A. (2008). Major Matters: A Comparison of the Within-Major Gender Pay Gap across College Majors for Early-Career Graduates. Industrial Relations, 47, 625-650.

Morgan, S. L., Gelbgiser, D., \& Weeden, K. (2013). Feeding the pipeline: Gender, occupational plans, and college major selection. Social Science Research, 42, 989-1005.

Ochsenfeld, F. (2014). Why Do Women's Fields of Study Pay Less? A Test of Devaluation, Human Capital, and Gender Role Theory. European Sociological Review, 30, 536-548.

Ochsenfeld, F. (2015). Replication Data for: Preferences, Constraints, and the Process of Sex Segregation in College Majors: A Choice Analysis. http://dx.doi.org/10.7910/DVN/HGCRRE, Harvard Dataverse, V1.

Parsons, T. (1935). The Place of Ultimate Values in Sociological Theory. International Journal of Ethics, 45, 282-316.

Penner, A., \& Paret, M. (2008). Gender differences in mathematics achievement: Exploring the early grades and extremes. Social Science Research, 37, 239-253.

Petersen, T., \& Morgan, L. A. (1995). Separate and Unequal. Occupation-Establishment Sex Segregation and the Gender Wage Gap. American Journal of Sociology, 101, 329-365.

Polachek, S. W. (1981). Occupational Self-Selection. A Human Capital Approach to Sex Differences in Occupational Structure. The Review of Economics and Statistics, 63, 60-69. 
Pollmann-Schult, M. (2009). Geschlechterunterschiede in den Arbeitswerten. Eine Analyse für die alten Bundesländer 1980-2000. Zeitschrift für ArbeitsmarktForschung, 42, 140-154.

Reskin, B. F., \& Roos, P. A. (1990). Job Queues, Gender Queues. Explaining Women's Inroads into Male Occupations. Philadelphia: Temple University Press.

Riegle-Crumb, C., King, B., Grodsky, E., \& Muller, C. (2012). The More Things Change, the More They Stay the Same? Prior Achievement Fails to Explain Gender Inequality in Entry Into STEM College Majors Over Time. American Educational Research Journal, 49, 1048-1073.

Schimpl-Neimanns, B., \& Herwig, A. (2011). Mikrozensus Scientific Use File 2009: Dokumentation und Datenaufbereitung. GESIS. Cologne.

Shauman, K. A. (2006). Occupational sex segregation and the earnings of occupations. What causes the link among college-educated workers? Social Science Research, 35, 577-619.

Shauman, K. A. (2009). Are there sex differences in the utilization of educational capital among college-educated workers? Social Science Research, 38, 535-571.

Shu, X., \& Marini, M. M. (1998). Gender-Related Change in Occupational Aspirations. Sociology of Education, 71, 43-67.

Smyth, E., \& Steinmetz, S. (2008). Field of Study and Gender Segregation in European Labour Markets. International Journal of Comparative Sociology, 49, 257-281.

Steele, J., James, J., \& Chait Barnett, R. (2002). Learning in a Man's World. Examining the Perceptions of Undergraduate Women in Male-Dominated Academic Areas. Psychology of Women Quarterly, 26, 46-50.

Stigler, G., \& Becker, G. (1977). De Gustibus Non Est Disputandum. The American Economic Review, 67, 76-90.

Su, R., Rounds, J., \& Armstrong, P. (2009). Men and Things, Women and People: A Meta-Analysis of Sex Differences in Interests. Psychological Bulletin, 135, 859-884.

Turner, S., \& Bowen, W. (1999). Choice of Major: The Changing (Unchanging) Gender Gap. Industrial and Labor Relations Review, 52, 289-313.

Vaisey, S. (2010). What People Want: Rethinking Poverty, Culture, and Educational Attainment. The Annals of the American Academy of Political and Social Science, 629, 75-101.

van de Werfhorst, H., \& Kraaykamp, G. (2001). Four Field-Related Educational Resources and their Impact on Labor, Consumption, and Sociopolitical Orientation. Sociology of Education, 74, 296-317.

Wagner, W., Kramer, J., Trautwein, U., Lüdtke, O., Nagy, G., Jonkmann, K., Maaz, K., Meixner, S. \& Schilling, J. (2011). Upper secondary education in academic school tracks and the transition from school to secondary education and the job market. In H.-P. Blossfeld, H.-G. Roßbach \& J. von Maurice (Eds.), Education as a Lifelong Process. The German National Educational Panel Study (NEPS) (pp. 233-249). Wiesbaden: VS.

Wang, M.-T., Eccles, J., \& Kenny, S. (2013). Not Lack of Ability but More Choice: Individual and Gender Differences in Choice of Careers in Science, Technology, Engineering, and Mathematics. Psychological Science, 24, 770-775.

Wilson, K. L., \& Boldizar, J. P. (1990). Gender Segregation in Higher Education. Effects of Aspirations, Mathematics Achievement, and Income. Sociology of Education, 63, 62-74.

Wissenschaftsrat. (2014). Institutionelle Perspektiven der empirischen Wissenschafts- und Hochschulforschung in Deutschland. Retrieved from German Council of Science and Humanities website: http://www.wissenschaftsrat.de/download/archiv/3821-14.pdf

Wrong, D. (1961). The oversocialized conception of man in modern sociology. American Sociological Review, 26, 183-193.

Xie, Y., \& Shauman, K. A. (1997). Modeling the Sex-Typing of Occupational Choice. Influences of Occupational Structure. Sociological Methods \& Research, 26, 233-261.

Xie, Y., \& Shauman, K. A. (2003). Women in Science. Career Processes and Outcomes. Cambridge: Harvard UP.

Zafar, B. (2013). College Major Choice and the Gender Gap. The Journal of Human Resources, 48, 545-595.

Zeng, Z., \& Xie, Y. (2008). A Preference-Opportunity-Choice Framework with Applications to Intergroup Friendship. American Journal of Sociology, 114, 615-648. 


\section{Supplementary material}

Table A1: Vocational interests by gender.

To what extent do these activities interest you

or how much do you enjoy doing these?

\section{Realistic}

Building or assembling things

Preparing something according to a plan or a sketch

Working with metal/wood,

creating things from metal/wood

Investigative

Observing and analyzing things in detail

Conducting experiments in a test laboratory

Analyzing things through a microscope

Artistic

Drawing pictures

Designing something artistically

Reading or interpreting poetry/ literature Social

Championing the needs of others

Helping sick people

Caring for children or adults in need

Enterprising

Negotiating with other people

Appearing in public to back something

Telling other people what they should do

$$
\text { Conventional }
$$

Keeping lists or records of things

Counting and sorting things

very little

Females Males

(n)

.09

.079

little

$.037 \quad .349-.164$

$.427 \quad .215$

$.010 \quad .006$

$.240 \quad .121$

$.287 \quad .193$

$.193 \quad 320$

$157 \quad .278$

$.118 \quad .234$

$.097 \quad .241$

.290

$$
.243
$$

.171

$.005 \quad .006$

.057

.04

.089

.104

.030

$$
.219
$$

.170

$.011 \quad .015$

$.044 \quad .047$

$.041 \quad .029$

$$
.125
$$

$$
\begin{aligned}
& .125 \\
& .217 \\
& .218
\end{aligned}
$$

218

.187

.102
203

.308

.433

.094

$.308 \quad .300$

Note: Weighted estimates; Source: NEPS-SC5 
Table A2: Descriptive statistics comparing observations in sample and observations deleted due to missing values.

\begin{tabular}{|c|c|c|c|c|c|c|}
\hline & \multicolumn{2}{|c|}{ Sample } & \multicolumn{2}{|c|}{ Deleted } & \multirow[b]{2}{*}{ Diff. } & \multirow[b]{2}{*}{ Wald test } \\
\hline & Mean & s.e. & Mean & s.e. & & \\
\hline Female $(0 / 1)$ & .543 & .0064 & .615 & .0460 & -.072 & .121 \\
\hline Realistic & .455 & .0030 & .446 & .0205 & .009 & .665 \\
\hline Investigative & .525 & .0029 & .496 & .0187 & .029 & .124 \\
\hline Artistic & .456 & .0032 & .478 & .0240 & -.022 & .367 \\
\hline Social & .612 & .0028 & .630 & .0190 & -.018 & .357 \\
\hline Enterprising & .592 & .0024 & .592 & .0190 & .001 & .964 \\
\hline Conventional & .422 & .0025 & .392 & .0179 & .031 & .092 \\
\hline Math grade - German grade & -.103 & .0428 & -1.790 & .9859 & 1.687 & .087 \\
\hline Earning well & .716 & .0025 & .730 & .0182 & -.014 & .455 \\
\hline Pleasant working hours & .692 & .0028 & .720 & .0198 & -.028 & .162 \\
\hline $\mathrm{N}$ & \multicolumn{2}{|c|}{9,109} & \multicolumn{2}{|c|}{$\leq 174$} & & \\
\hline
\end{tabular}

Note: Weighted estimates; Source: NEPS-SC5. 
Table : Description of variables.

\begin{tabular}{|c|c|c|}
\hline Variable & Description & Source \\
\hline \multicolumn{3}{|c|}{ Person characteristics used in main analysis } \\
\hline $\begin{array}{l}\text { Major chosen } \\
\text { (dependent } \\
\text { variable) }\end{array}$ & $\begin{array}{l}\text { Coding based on the survey question "What subjects have } \\
\text { you enrolled for?", 'Please specify first subject”. The } \\
\text { following subjects were merged together: 'special needs } \\
\text { pedagogy' with 'pedagogy', 'surveying and mapping' } \\
\text { with 'civil engineering', 'traffic engineering' with 'civil } \\
\text { engineering', 'design' with 'architecture and interior } \\
\text { design', 'fine arts', 'performing arts', 'music, and } \\
\text { musicology' with 'art and art history', 'dentistry' with } \\
\text { 'medical science', 'urban and regional planning' with } \\
\text { 'geography', 'philosophy with history', non-German } \\
\text { philologies with 'cultural sciences', 'political science' and } \\
\text { 'social and economic studies' with 'social sciences', } \\
\text { 'forestry' with 'agronomy', as well as the more } \\
\text { management intensive variant of industrial engineering } \\
\text { with the more engineering intensive variant. }\end{array}$ & NEPS-SC5, wave 1 \\
\hline Female & Based on the variable "gender". & NEPS-SC5, wave 1 \\
\hline Realistic & $\begin{array}{l}\text { Composite index based on three items with 6-point Likert } \\
\text { scale: "building or assembling things", "preparing } \\
\text { something according to a plan or a sketch", "working with } \\
\text { metal/wood, creating things from metal/wood". }\end{array}$ & NEPS-SC5, wave 1 \\
\hline Investigative & $\begin{array}{l}\text { Composite index based on three items with 6-point Likert } \\
\text { scale: "observing and analyzing things in detail", } \\
\text { "conducting experiments in a test laboratory", "analyzing } \\
\text { things through a microscope". }\end{array}$ & NEPS-SC5, wave 1 \\
\hline Artistic & $\begin{array}{l}\text { Composite index based on three items with 6-point Likert } \\
\text { scale: "drawing pictures", "designing something } \\
\text { artistically", "reading or interpreting poetry/ literature". }\end{array}$ & NEPS-SC5, wave 1 \\
\hline Social & $\begin{array}{l}\text { Composite index based on three items with 6-point Likert } \\
\text { scale: "championing the needs of others", "helping sick } \\
\text { people", "caring for children or adults in need". }\end{array}$ & NEPS-SC5, wave 1 \\
\hline Enterprising & $\begin{array}{l}\text { Composite index based on three items with 6-point Likert } \\
\text { scale: "negotiating with other people", "appearing in } \\
\text { public to back something", "telling other people what they } \\
\text { should do". }\end{array}$ & NEPS-SC5, wave 1 \\
\hline Conventional & $\begin{array}{l}\text { Composite index based on three items with 6-point Likert } \\
\text { scale: "keeping lists or records of things", "counting and } \\
\text { sorting things", "monitoring adherence to regulations". }\end{array}$ & NEPS-SC5, wave 1 \\
\hline $\begin{array}{l}\text { Relative math } \\
\text { grade }\end{array}$ & $\begin{array}{l}\text { Result of the subtraction of the response to the item "how } \\
\text { many points did you have in German in your final school } \\
\text { semester?" from the response to the item "how many } \\
\text { points did you have in mathematics in your final school } \\
\text { semester?" Where missing, responses were drawn from } \\
\text { the items "What was your last mid-year grade in } \\
\text { German?" and "What was your last mid-year grade in } \\
\text { mathematics?" }\end{array}$ & NEPS-SC5, wave 1 \\
\hline Earning well & $\begin{array}{l}\text { Variable based on the item "In the following we deal with } \\
\text { things which might be important to a vocational activity. } \\
\text { How important do you personally find this things, } \\
\text { independent of your current situation? Please give your }\end{array}$ & NEPS-SC5, wave 3 \\
\hline
\end{tabular}




\begin{tabular}{|c|c|c|}
\hline & $\begin{array}{l}\text { answer on a scale from } 1 \text { to } 6 . \text { ' } 1 \text { ' means, that this aspect is } \\
\text { very unimportant to you, ' } 6 \text { ' means that it is very } \\
\text { important to you. - How important is a good remuneration } \\
\text { to you?" }\end{array}$ & \\
\hline $\begin{array}{l}\text { Pleasant work } \\
\text { hours }\end{array}$ & $\begin{array}{l}\text { Variable based on the item "In the following we deal with } \\
\text { things which might be important to a vocational activity. } \\
\text { How important do you personally find this things, } \\
\text { independent of your current situation? Please give your } \\
\text { answer on a scale from } 1 \text { to } 6 \text {. ' } 1 \text { ' means, that this aspect is } \\
\text { very unimportant to you, ' } 6 \text { ' means that it is very } \\
\text { important to you. - How important are pleasant working } \\
\text { hours to you?" }\end{array}$ & NEPS-SC5, wave 3 \\
\hline \multicolumn{3}{|c|}{ Additional person characteristics used for robustness check only } \\
\hline Career & $\begin{array}{l}\text { Variable based on the item "In the following we deal with } \\
\text { things which might be important to a vocational activity. } \\
\text { How important do you personally find this things, } \\
\text { independent of your current situation? Please give your } \\
\text { answer on a scale from } 1 \text { to } 6 \text {. ' } 1 \text { ' means, that this aspect is } \\
\text { very unimportant to you, ' } 6 \text { ' means that it is very } \\
\text { important to you. - How important are the chances to } \\
\text { move up the career ladder to you?" }\end{array}$ & NEPS-SC5, wave 3 \\
\hline Traditionalist & $\begin{array}{l}\text { Variable based on the 4-point Likert-scaled item "Now we } \\
\text { would still be interested in knowing what you think about } \\
\text { family and children in general. For the following } \\
\text { statements, please indicate the extent to which you agree } \\
\text { with them. - The man's job is to earn money; the woman's } \\
\text { job is to take care of the household and family." }\end{array}$ & NEPS-SC5, wave 4 \\
\hline Tradit. hhduties & $\begin{array}{l}\text { Variable based on the 4-point Likert-scaled item "Now we } \\
\text { would still be interested in knowing what you think about } \\
\text { family and children in general. For the following } \\
\text { statements, please indicate the extent to which you agree } \\
\text { with them. - Men and women should have the same duties } \\
\text { in the household." Recoded to measure disagreement with } \\
\text { egalitarian arrangement. }\end{array}$ & NEPS-SC5, wave 4 \\
\hline \multicolumn{3}{|c|}{ Major characteristics } \\
\hline Math intensity & $\begin{array}{l}\text { Variable aggregated from responses to the 4-point Likert- } \\
\text { scaled item "To what extent were knowledge and skills } \\
\text { in the following areas needed in your studies? - } \\
\text { Mathematics" }\end{array}$ & NEPS-SC5, wave 2 \\
\hline Care & $\begin{array}{l}\text { The following majors were assigned the value " } 100 \text { ": } \\
\text { 'social work', 'pedagogy', 'state teacher', 'psychology', } \\
\text { 'medical science'. All other majors were assigned the } \\
\text { value "0". }\end{array}$ & Own coding \\
\hline $\begin{array}{l}\text { Diff. parents' } \\
\text { approval }\end{array}$ & $\begin{array}{l}\text { Proportion of male respondents who responded to the 5- } \\
\text { point Likert scaled item "What do your parents and } \\
\text { friends think about the fact that you are studying for a } \\
\text { degree, and about the subject you are studying? } \\
\text { - My parents think I have chosen a good degree subject" } \\
\text { either with "applies completely" or "applies", subtracted } \\
\text { from the proportion of female respondents who responded } \\
\text { to the same item either with "applies completely" or } \\
\text { "applies". }\end{array}$ & NEPS-SC5, wave 1 \\
\hline
\end{tabular}




\begin{tabular}{|c|c|c|}
\hline $\begin{array}{l}\text { Diff. friends' } \\
\text { approval }\end{array}$ & $\begin{array}{l}\text { Proportion of male respondents who responded to the 5- } \\
\text { point Likert scaled item "What do your parents and } \\
\text { friends think about the fact that you are studying for a } \\
\text { degree, and about the subject you are studying? } \\
\text { - My friends think I have chosen a good degree subject" } \\
\text { either with "applies completely" or "applies", subtracted } \\
\text { from the proportion of female respondents who responded } \\
\text { to the same item either with "applies completely" or } \\
\text { "applies". }\end{array}$ & NEPS-SC5, wave 1 \\
\hline Wage level & $\begin{array}{l}\text { Coefficients for a set of major dummy variables from a } \\
\text { regression of hourly wages on these dummies and a set of } \\
\text { productivity-related characteristics (table A6), scaled to } \\
\text { measure the difference in the wage level relative to } \\
\text { economic sciences (the reference category) in } \\
\text { percentages. Regression sample restricted to persons with } \\
\text { completed college education, aged 25-55, working at least } \\
20 \text { hours per week. }\end{array}$ & $\begin{array}{l}\text { German Micro } \\
\text { Census 2007, } \\
\text { 2008, 2009 } \\
\text { (pooled) }\end{array}$ \\
\hline Overwork norms & $\begin{array}{l}\text { Hours worked per week (top coded at } 80 \text { ) on average by } \\
\text { persons working at least } 35 \text { hours per week. }\end{array}$ & $\begin{array}{l}\text { German Micro } \\
\text { Census } 2007 \text {, } \\
2008,2009 \\
\text { (pooled) }\end{array}$ \\
\hline Discrimination & $\begin{array}{l}\text { Proportion of females who responded to the item "Which } \\
\text { of the following criteria, in your opinion, are important in } \\
\text { order to be successful when looking for a job - the "right" } \\
\text { gender." with either "very important" or "important". }\end{array}$ & $\begin{array}{l}\text { HIS graduate panel } \\
\text { studies 1997, } 2001 \\
\text { (pooled), wave } 2\end{array}$ \\
\hline
\end{tabular}


Table A4: Determinants of college major choice, parameters from a conditional logit model including 'other majors' as one choice option.

\begin{tabular}{|c|c|c|}
\hline Person characteristic. $\mathrm{x}$ major char. & Odds ratio & $\begin{array}{l}\text { Odds ratio } \\
\text { (semi-std.) }\end{array}$ \\
\hline \multicolumn{3}{|l|}{ Gender Essentialism } \\
\hline $\begin{array}{l}\text { Preterences: vocational interests } \\
\text { Realistic x math intensity }\end{array}$ & $\begin{array}{l}1.062^{* * *} \\
(.0037)\end{array}$ & $\begin{array}{l}1.486^{\star * *} \\
(.0340)\end{array}$ \\
\hline Realistic $x$ care & $\begin{array}{l}.095^{\star \star} \\
(.0016)\end{array}$ & $\begin{array}{l}.954^{\star \star} \\
(.0148)\end{array}$ \\
\hline Investigative $\mathrm{x}$ math intensity & $\begin{array}{l}1.054^{* * *} \\
(.0032)\end{array}$ & $\begin{array}{l}1.408^{\star \star *} \\
(.0277)\end{array}$ \\
\hline Investigative $\mathrm{x}$ care & $\begin{array}{l}1.007^{* * *} \\
(.0014)\end{array}$ & $\begin{array}{l}1.067^{* \star *} \\
(.0142)\end{array}$ \\
\hline Artistic $x$ math intensity & $\begin{array}{l}.951^{* * *} \\
(.0029)\end{array}$ & $\begin{array}{l}.700^{* * *} \\
(.0150)\end{array}$ \\
\hline Artistic $\times$ care & $\begin{array}{l}.999 \\
(.0013)\end{array}$ & $\begin{array}{l}.991 \\
(.0135)\end{array}$ \\
\hline Social $x$ math intensity & $\begin{array}{l}.964^{* * *} \\
(.0033)\end{array}$ & $\begin{array}{l}.795^{\star \star *} \\
(.0172)\end{array}$ \\
\hline Social $x$ care & $\begin{array}{l}1.055^{\star \star \star} \\
(.0018)\end{array}$ & $\begin{array}{l}1.638^{\star \star \star} \\
(.0261)\end{array}$ \\
\hline Enterprising $x$ math intensity & $\begin{array}{l}.995 \\
(.0037)\end{array}$ & $\begin{array}{l}.975 \\
(.0193)\end{array}$ \\
\hline Enterprising $x$ care & $\begin{array}{l}.994^{* * *} \\
(.0017)\end{array}$ & $\begin{array}{l}.952^{* * *} \\
(.0125)\end{array}$ \\
\hline Conventional $\mathrm{x}$ math intensity & $\begin{array}{c}.999 \\
(.0034)\end{array}$ & $\begin{array}{c}.994 \\
(.0186)\end{array}$ \\
\hline Conventional $\mathrm{x}$ care & $\begin{array}{l}0.997 \\
(.0016)\end{array}$ & $\begin{array}{l}.980 \\
(.0126)\end{array}$ \\
\hline \multicolumn{3}{|l|}{ Abilities: educational preparation } \\
\hline Rel. math grade $x$ math intensity & $\begin{array}{l}1.003^{* * *} \\
(.0002)\end{array}$ & $\begin{array}{l}1.268^{* * *} \\
(.0248)\end{array}$ \\
\hline \multicolumn{3}{|l|}{ Constraints: social norms } \\
\hline Female $\mathrm{x}$ diff. parents' approval & $\begin{array}{l}.977^{\star *} \\
(.0074)\end{array}$ & $\begin{array}{l}.943^{\star *} \\
(.0178)\end{array}$ \\
\hline Female $x$ diff. friends' approval & $\begin{array}{l}1.062^{* * *} \\
(.0051)\end{array}$ & $\begin{array}{l}1.287^{* * *} \\
(.0256)\end{array}$ \\
\hline \multicolumn{3}{|l|}{$\begin{array}{l}\text { Separate spheres } \\
\text { Preferences }\end{array}$} \\
\hline Earning well $x$ wage level & $\begin{array}{l}1.053^{\star \star \star} \\
(.0076)\end{array}$ & $\begin{array}{l}1.126^{\star \star *} \\
(.0185)\end{array}$ \\
\hline \multicolumn{3}{|l|}{ Constraints } \\
\hline Pleasant work hrs. x overwork norms & $\begin{array}{l}.863^{* * *} \\
(.0291)\end{array}$ & $\begin{array}{l}0.945^{\star \star *} \\
(.0121)\end{array}$ \\
\hline $\begin{array}{l}\text { Anticipated discrimination } \\
\text { Female } \mathrm{x} \text { discrimination }\end{array}$ & $\begin{array}{l}.985^{* * *} \\
(.0037)\end{array}$ & $\begin{array}{l}.949^{\star \star *} \\
(.0125)\end{array}$ \\
\hline Major fixed-effects & Yes & Yes \\
\hline$N=$ & 9,640 & 9,640 \\
\hline$J=$ & 24 & 24 \\
\hline
\end{tabular}


Table A5: Explanatory power of variables and variable groups for sex segregation in college majors, decomposition results from a mediation analysis on the basis of conditional logit models including 'other majors' as one choice option.

\begin{tabular}{|c|c|c|c|c|}
\hline & \multicolumn{2}{|c|}{$\begin{array}{l}\text { When adding term } \\
\text { to baseline model }\end{array}$} & \multicolumn{2}{|c|}{$\begin{array}{l}\text { When removing term } \\
\text { from full model }\end{array}$} \\
\hline & $\begin{array}{l}\text { OR for female } \\
x \text { prop.female }\end{array}$ & $\begin{array}{c}\text { Percentage } \\
\text { explained }\end{array}$ & $\begin{array}{l}\text { OR for female } \\
x \text { prop.female }\end{array}$ & $\begin{array}{c}\text { Percentage } \\
\text { explained }\end{array}$ \\
\hline Baseline model & 1.0451 & 0 & - & - \\
\hline Full model (all variables) & 1.0243 & 46.1 & - & - \\
\hline Essentialism (total) & 1.0246 & 45.4 & 1.0447 & 45.3 \\
\hline Preferences: vocational interests (total) & 1.0282 & 37.4 & 1.0408 & 36.6 \\
\hline Realistic x [math intensity, care] & 1.0396 & 12.0 & 1.0308 & 14.5 \\
\hline Investigative [math intensity, care] & 1.0441 & 2.0 & 1.0249 & 1.3 \\
\hline Artistic $x$ [math intensity, care] & 1.0397 & 12.0 & 1.0298 & 12.3 \\
\hline Social x [math intensity, care] & 1.0392 & 12.9 & 1.0293 & 11.1 \\
\hline Enterprising $x$ [math intensity, care] & 1.0457 & -1.4 & 1.0241 & -0.4 \\
\hline Conventional x [math intensity, care] & 1.0455 & -1.1 & 1.0240 & -0.7 \\
\hline \multicolumn{5}{|l|}{ Abilities: educational preparation (total) } \\
\hline Rel. math grade $x$ math intensity & 1.0425 & 5.8 & 1.0246 & 0.7 \\
\hline Constraints: social norms (total) & 1.0440 & 2.3 & 1.0276 & 7.3 \\
\hline Female $x$ diff. parents' approval & 1.0452 & -0.4 & 1.0238 & -1.2 \\
\hline Female $x$ diff. friends' approval & 1.0438 & 2.7 & 1.0288 & 10.1 \\
\hline Separate spheres (total) & 1.0451 & -0.1 & 1.0238 & -1.0 \\
\hline \multicolumn{5}{|l|}{ Preferences } \\
\hline Earning well $\mathrm{x}$ wage level & 1.0450 & 0.0 & 1.0240 & -0.6 \\
\hline \multicolumn{5}{|l|}{ Constraints } \\
\hline Pleasant work hrs. x overwork norms & 1.0451 & 0.0 & 1.0240 & -0.6 \\
\hline \multicolumn{5}{|l|}{ Anticipated discrimination } \\
\hline Female $\mathrm{x}$ discrimination & 1.0445 & 1.1 & 1.0250 & 1.5 \\
\hline
\end{tabular}


Table A6: Determinants of (logged) hourly wages.

\begin{tabular}{|c|c|c|}
\hline & coef. & s.e. \\
\hline College major (dummies) & \multicolumn{2}{|c|}{ Yes (see table A3) } \\
\hline East Germany (0/1) & -0.260 & $(.0047)$ \\
\hline Experience (years) & .0311 & $(.00135)$ \\
\hline Experience (squared) & -.0009 & $(.00004)$ \\
\hline Age (years) & .0395 & $(.00358)$ \\
\hline Age (squared) & -.0003 & $(.00004)$ \\
\hline Full Abitur (0/1) & .073 & $(.0056)$ \\
\hline $\operatorname{PhD}(0 / 1)$ & .223 & $(.0106)$ \\
\hline Full university $(0 / 1)$ & .067 & $(.0050)$ \\
\hline Cohort: 2008 (0/1) & .019 & $(.0047)$ \\
\hline Cohort: 2009 (0/1) & .054 & $(.0047)$ \\
\hline Constant & 1.385 & $(.0670)$ \\
\hline $\mathrm{N}$ & \multicolumn{2}{|c|}{60,173} \\
\hline$R^{2}$ & \multicolumn{2}{|c|}{.220} \\
\hline
\end{tabular}

Notes: WLS estimation; Source: Micro Census. 
Table A7: Descriptive statistics for 23 college majors.

\begin{tabular}{|c|c|c|c|c|c|c|c|c|c|c|c|}
\hline & \multicolumn{2}{|c|}{ Prop. fem. } & \multicolumn{2}{|c|}{ Wage level } & \multicolumn{2}{|c|}{ Math intensity } & \multirow[t]{2}{*}{ Care } & \multicolumn{2}{|c|}{ Overwork norm } & \multicolumn{2}{|c|}{$\begin{array}{c}\text { Discrim. against } \\
\text { women }\end{array}$} \\
\hline & mean & s.e. & mean & s.e. & mean & s.e. & & mean & s.e. & mean & s.e. \\
\hline Pedagogy & 91.2 & 1.9 & -19.1 & 1.0 & 23.3 & 1.7 & 100 & 42.8 & 0.2 & 25.7 & 2.2 \\
\hline Psychology & 86.6 & 2.1 & -12.1 & 1.8 & 70.9 & 1.5 & 100 & 44.5 & 0.3 & 21.4 & 3.3 \\
\hline Social work & 86.0 & 2.0 & -20.1 & 0.9 & 13.3 & 1.2 & 100 & 42.2 & 0.2 & 35.1 & 2.3 \\
\hline Philology/cultural studies & 82.8 & 1.6 & -21.7 & 1.5 & 20.1 & 1.4 & 0 & 44.3 & 0.3 & 29.0 & 2.0 \\
\hline Biology & 73.8 & 2.6 & -23.3 & 1.5 & 74.3 & 1.8 & 0 & 45.9 & 0.3 & 34.0 & 4.2 \\
\hline State Teacher & 73.3 & 0.7 & -9.8 & 0.7 & 46.7 & 0.7 & 100 & 44.9 & 0.1 & 19.2 & 1.8 \\
\hline Medical sciences & 67.9 & 2.0 & 11.3 & 1.0 & 46.1 & 1.2 & 100 & 51.8 & 0.2 & 44.8 & 2.5 \\
\hline Arts, art sciences & 67.4 & 4.1 & -28.8 & 1.7 & 16.2 & 2.6 & 0 & 45.1 & 0.3 & 29.7 & 3.8 \\
\hline Architecture, int. design, design & 64.9 & 3.5 & -19.3 & 1.1 & 41.8 & 2.5 & 0 & 46.4 & 0.2 & 30.2 & 2.7 \\
\hline Social science, political science & 64.8 & 2.1 & -14.8 & 2.5 & 49.8 & 1.3 & 0 & 46.1 & 0.5 & 38.7 & 3.9 \\
\hline Law & 58.3 & 2.2 & -3.3 & 1.0 & 21.7 & 1.4 & 0 & 47.5 & 0.2 & 35.0 & 3.2 \\
\hline Economic sciences & 57.6 & 1.3 & 0.0 & - & 73.4 & 0.8 & 0 & 46.4 & 0.1 & 30.8 & 1.7 \\
\hline Geography & 52.6 & 3.5 & -20.6 & 1.7 & 51.9 & 2.5 & 0 & 45.2 & 0.3 & 29.9 & 3.7 \\
\hline History/Philosophy & 49.8 & 4.0 & -24.5 & 2.2 & 22.7 & 2.7 & 0 & 45.9 & 0.4 & 41.4 & 6.2 \\
\hline Chemistry & 46.6 & 3.2 & -8.6 & 1.2 & 81.1 & 1.9 & 0 & 45.5 & 0.2 & 36.1 & 4.8 \\
\hline Agronomy, Forestry & 40.9 & 3.6 & -21.6 & 1.5 & 69.6 & 3.1 & 0 & 45.1 & 0.3 & 40.5 & 6.3 \\
\hline Mathematics & 38.4 & 3.1 & 2.6 & 1.6 & 93.3 & 1.4 & 0 & 44.8 & 0.3 & 26.4 & 4.2 \\
\hline Civil engineering & 29.7 & 2.4 & -7.4 & 0.9 & 84.7 & 2.0 & 0 & 46.2 & 0.2 & 39.3 & 3.0 \\
\hline Physics & 22.5 & 2.7 & -6.0 & 1.5 & 94.1 & 1.4 & 0 & 45.8 & 0.3 & 32.8 & 6.8 \\
\hline Computer science & 20.8 & 1.7 & 6.0 & 0.9 & 82.3 & 1.5 & 0 & 45.0 & 0.2 & 23.1 & 4.6 \\
\hline Industrial engineering & 19.3 & 1.6 & 7.4 & 1.5 & 90.1 & 1.0 & 0 & 46.1 & 0.2 & 34.1 & 5.1 \\
\hline Mechanical engineering & 16.4 & 1.1 & 4.2 & 0.8 & 93.3 & 0.7 & 0 & 45.5 & 0.1 & 46.7 & 3.5 \\
\hline Electrical engineering & 9.2 & 1.7 & 5.0 & 0.8 & 95.0 & 1.1 & 0 & 45.0 & 0.1 & 33.0 & 8.3 \\
\hline
\end{tabular}




\begin{tabular}{|c|c|c|c|c|c|c|c|c|c|c|c|c|}
\hline & \multicolumn{6}{|c|}{ Prop. of parents approving } & \multicolumn{6}{|c|}{ Prop. of friends approving } \\
\hline & \multicolumn{2}{|c|}{ Females } & \multicolumn{2}{|c|}{ Males } & \multicolumn{2}{|c|}{ Diff. } & \multicolumn{2}{|c|}{ Females } & \multicolumn{2}{|c|}{ Males } & \multicolumn{2}{|c|}{ Diff. } \\
\hline & mean & s.e. & mean & s.e. & mean & s.e. & mean & s.e. & mean & s.e. & mean & s.e. \\
\hline Pedagogy & 74.9 & 3.2 & 66.4 & 11.7 & 8.5 & 11.9 & 63.1 & 3.6 & 48.1 & 12.9 & 15.0 & 13.0 \\
\hline Psychology & 79.9 & 2.7 & 89.0 & 5.4 & -9.1 & 6.0 & 81.4 & 2.7 & 75.2 & 7.8 & 6.2 & 8.1 \\
\hline Social work & 76.4 & 2.6 & 84.0 & 6.9 & -7.6 & 7.3 & 67.7 & 2.8 & 50.0 & 9.1 & 17.7 & 9.4 \\
\hline Philology/cultural studies & 71.6 & 2.1 & 73.2 & 5.2 & -1.6 & 5.6 & 62.6 & 2.3 & 54.9 & 5.8 & 7.7 & 6.2 \\
\hline Biology & 75.1 & 3.1 & 75.1 & 5.5 & 0.1 & 6.3 & 67.8 & 3.3 & 60.4 & 6.2 & 7.4 & 7.0 \\
\hline State Teacher & 84.7 & 0.6 & 80.0 & 1.3 & 4.8 & 1.5 & 67.5 & 0.8 & 60.1 & 1.6 & 7.4 & 1.8 \\
\hline Medical sciences & 94.1 & 1.2 & 90.1 & 2.6 & 3.9 & 2.9 & 83.5 & 2.1 & 87.2 & 2.8 & -3.7 & 3.5 \\
\hline Arts, art sciences & 64.5 & 5.0 & 60.4 & 8.5 & 4.1 & 9.8 & 68.1 & 5.0 & 65.5 & 8.5 & 2.7 & 9.8 \\
\hline Architecture, int. design, design & 77.8 & 4.0 & 75.4 & 6.1 & 2.3 & 7.3 & 80.9 & 4.0 & 83.7 & 5.2 & -2.7 & 6.5 \\
\hline Social science, political science & 61.5 & 2.7 & 65.4 & 3.9 & -3.9 & 4.7 & 56.0 & 2.7 & 58.8 & 4.0 & -2.7 & 4.8 \\
\hline Law & 86.1 & 2.1 & 87.9 & 2.7 & -1.7 & 3.4 & 57.1 & 3.0 & 63.5 & 3.9 & -6.4 & 5.0 \\
\hline Economic sciences & 83.5 & 1.4 & 85.2 & 1.6 & -1.7 & 2.1 & 60.9 & 1.8 & 56.9 & 2.4 & 4.0 & 3.0 \\
\hline Geography & 78.0 & 4.1 & 85.9 & 4.0 & -8.0 & 5.7 & 66.6 & 4.6 & 63.5 & 5.8 & 3.1 & 7.4 \\
\hline History/Philosophy & 65.5 & 5.4 & 60.2 & 6.6 & 5.3 & 8.5 & 61.4 & 5.6 & 47.8 & 6.7 & 13.6 & 8.7 \\
\hline Chemistry & 77.8 & 4.2 & 80.2 & 3.7 & -2.4 & 5.5 & 66.3 & 4.7 & 66.2 & 4.6 & 0.1 & 6.6 \\
\hline Agronomy, Forestry & 88.6 & 3.7 & 85.1 & 4.6 & 3.5 & 5.9 & 63.0 & 5.6 & 60.3 & 5.6 & 2.8 & 7.9 \\
\hline Mathematics & 82.4 & 4.7 & 79.5 & 3.7 & 2.9 & 5.9 & 47.8 & 5.5 & 52.5 & 4.6 & -4.7 & 7.2 \\
\hline Civil engineering & 80.1 & 4.0 & 83.0 & 2.9 & -2.9 & 4.9 & 72.0 & 4.6 & 68.7 & 3.5 & 3.3 & 5.7 \\
\hline Physics & 82.6 & 5.4 & 90.7 & 2.4 & -8.1 & 5.9 & 49.7 & 7.4 & 58.6 & 4.0 & -8.9 & 8.4 \\
\hline Computer science & 78.8 & 4.0 & 82.8 & 2.1 & -4.0 & 4.5 & 51.2 & 4.9 & 66.3 & 2.6 & -15.1 & 5.5 \\
\hline Industrial engineering & 88.4 & 3.3 & 88.9 & 1.8 & -0.5 & 3.7 & 70.8 & 4.5 & 71.5 & 2.5 & -0.7 & 5.1 \\
\hline Mechanical engineering & 81.6 & 3.2 & 90.7 & 1.2 & -9.1 & 3.4 & 62.8 & 4.0 & 73.6 & 1.8 & -10.8 & 4.3 \\
\hline Electrical engineering & 90.8 & 5.4 & 88.3 & 2.3 & 2.6 & 5.7 & 55.2 & 11.1 & 65.9 & 3.3 & -10.7 & 11.4 \\
\hline
\end{tabular}

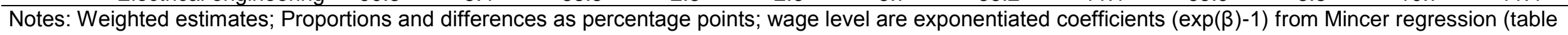
A6) with economic sciences as reference category. Sources: Micro Census 2007, 2008, 2009; HIS graduate panel studies 1997,2001 ; NEPS-SC5. 
Table A8: Determinants of college major choice, parameters from a conditional logit model with additional variables for separate spheres.

\begin{tabular}{|c|c|c|}
\hline Person characteristic. $\mathrm{x}$ major char. & Odds ratio & $\begin{array}{l}\text { Odds ratio } \\
\text { (semi-std.) }\end{array}$ \\
\hline \multicolumn{3}{|l|}{$\begin{array}{l}\text { Gender Essentialism } \\
\text { Preferences: vocational interests }\end{array}$} \\
\hline Realistic $x$ math intensity & $\begin{array}{l}1.065^{\star * *} \\
(.0048)\end{array}$ & $\begin{array}{l}1.524^{\star * *} \\
(.0459)\end{array}$ \\
\hline Realistic $x$ care & $\begin{array}{l}.995^{*} \\
(.0021)\end{array}$ & $\begin{array}{c}.956^{*} \\
(.0195)\end{array}$ \\
\hline Investigative $\mathrm{x}$ math intensity & $\begin{array}{c}1.060^{\star * *} \\
(.0043)\end{array}$ & $\begin{array}{c}1.468^{\star \star *} \\
(.0390)\end{array}$ \\
\hline Investigative $\mathrm{x}$ care & $\begin{array}{l}1.012^{* \star *} \\
(.0019)\end{array}$ & $\begin{array}{c}1.1167^{* * *} \\
(.0200)\end{array}$ \\
\hline Artistic $x$ math intensity & $\begin{array}{l}.9496^{\star \star *} \\
(.0037)\end{array}$ & $\begin{array}{l}.6871^{* * *} \\
(.0196)\end{array}$ \\
\hline Artistic $\times$ care & $\begin{array}{l}.996^{*} \\
(.0017)\end{array}$ & $\begin{array}{l}.961^{*} \\
(.0172)\end{array}$ \\
\hline Social $x$ math intensity & $\begin{array}{l}.965^{\star * *} \\
(.0043)\end{array}$ & $\begin{array}{l}.796^{\star * *} \\
(.0230)\end{array}$ \\
\hline Social $x$ care & $\begin{array}{l}1.060^{* \star \star} \\
(.0023)\end{array}$ & $\begin{array}{l}1.725^{\star \star *} \\
(.0355)\end{array}$ \\
\hline Enterprising $\mathrm{x}$ math intensity & $\begin{array}{c}.991 \\
(.0047)\end{array}$ & $\begin{array}{c}.952 \\
(.0248)\end{array}$ \\
\hline Enterprising $x$ care & $\begin{array}{l}.9933^{\star *} \\
(.0021)\end{array}$ & $\begin{array}{l}.947^{* *} \\
(.0163)\end{array}$ \\
\hline Conventional $\mathrm{x}$ math intensity & $\begin{array}{c}.998 \\
(.0044)\end{array}$ & $\begin{array}{c}.987 \\
(.0243)\end{array}$ \\
\hline Conventional $\mathrm{x}$ care & $\begin{array}{c}.999 \\
(.0020)\end{array}$ & $\begin{array}{c}.992 \\
(.0166)\end{array}$ \\
\hline \multicolumn{3}{|l|}{ Abilities: educational preparation } \\
\hline Rel. math grade $x$ math intensity & $\begin{array}{l}1.002^{\star * *} \\
(.0003)\end{array}$ & $\begin{array}{c}1.272^{* \star *} \\
(.0329)\end{array}$ \\
\hline \multicolumn{3}{|l|}{ Constraints: social norms } \\
\hline Female $x$ diff. parents' approval & $\begin{array}{l}.968^{\star \star \star} \\
(.0095)\end{array}$ & $\begin{array}{l}.921^{\star * *} \\
(.0230)\end{array}$ \\
\hline Female $x$ diff. friends' approval & $\begin{array}{l}1.069^{* * *} \\
(.0073)\end{array}$ & $\begin{array}{l}1.325^{\star * *} \\
(.0380)\end{array}$ \\
\hline \multicolumn{3}{|l|}{$\begin{array}{l}\text { Separate spheres } \\
\text { Preferences }\end{array}$} \\
\hline Earning well $\mathrm{x}$ wage level & $\begin{array}{c}1.039^{\star \star \star} \\
(.0106)\end{array}$ & $\begin{array}{l}1.095^{\star \star *} \\
(0.0264)\end{array}$ \\
\hline Career $\mathrm{x}$ wage level & $\begin{array}{c}1.047^{* * *} \\
(.0098)\end{array}$ & $\begin{array}{l}1.118^{\star * *} \\
(.0253)\end{array}$ \\
\hline Traditionalist $\mathrm{x}$ wage level & $\begin{array}{l}1.035^{\star *} \\
(.0113)\end{array}$ & $\begin{array}{l}1.092^{\star *} \\
(.0309)\end{array}$ \\
\hline Female $\mathrm{x}$ traditionalist $\mathrm{x}$ wage level & $\begin{array}{l}.958^{\star *} \\
(.0145)\end{array}$ & $\begin{array}{l}.896^{* *} \\
(.0350)\end{array}$ \\
\hline \multicolumn{3}{|l|}{ Constraints } \\
\hline Pleasant work hrs. x overwork norms & $\begin{array}{l}.850^{\star * *} \\
(.0353)\end{array}$ & $\begin{array}{l}.939^{\star * \star} \\
(.0152)\end{array}$ \\
\hline Tradit. hhduties $\mathrm{x}$ overwork norms & $\begin{array}{l}1.012 \\
(.0534)\end{array}$ & $\begin{array}{c}1.005 \\
(.0216)\end{array}$ \\
\hline
\end{tabular}


Anticipated discrimination

Major fixed-effects

Yes

Yes

$\begin{array}{lcc}\mathrm{N}= & 6,193 & 6,193 \\ \mathrm{~J}= & 23 & 23\end{array}$

Notes: Weighted estimates, standard errors in parentheses, ${ }^{*} \mathrm{p}<.05,{ }^{* *} \mathrm{p}<.01,{ }^{* * *}<.001$; right column reports coefficients for standardized independent variables; Sources: NEPS-SC5, Micro Census, HIS graduate panel studies.

Table A9: Explanatory power of variables and variable groups for sex segregation in college majors, decomposition results from a mediation analysis on the basis of conditional logit models with additional variables for separate spheres.

\begin{tabular}{|c|c|c|c|c|}
\hline & \multicolumn{2}{|c|}{$\begin{array}{l}\text { When adding term } \\
\text { to baseline model }\end{array}$} & \multicolumn{2}{|c|}{$\begin{array}{l}\text { When removing term } \\
\text { from full model }\end{array}$} \\
\hline & $\begin{array}{l}\text { OR for female } \\
x \text { prop.female }\end{array}$ & $\begin{array}{l}\text { Percentage } \\
\text { explained }\end{array}$ & $\begin{array}{l}\text { OR for female } \\
x \text { prop.female }\end{array}$ & $\begin{array}{c}\text { Percentage } \\
\text { explained }\end{array}$ \\
\hline Baseline model & 1.0446 & 0 & & \\
\hline Full model (all variables) & 1.0218 & 51.1 & & \\
\hline Essentialism (total) & 1.0223 & 49.9 & 1.0425 & 46.5 \\
\hline Preferences: vocational interests (total) & 1.0286 & 35.8 & 1.0369 & 33.7 \\
\hline Realistic x [math intensity, care] & 1.0395 & 11.4 & 1.0276 & 12.9 \\
\hline Investigative [math intensity, care] & 1.0434 & 2.7 & 1.0229 & 2.4 \\
\hline Artistic $\mathrm{x}$ [math intensity, care] & 1.0392 & 12.0 & 1.0267 & 11.0 \\
\hline Social x [math intensity, care] & 1.0395 & 11.4 & 1.0264 & 10.4 \\
\hline Enterprising $\mathrm{x}$ [math intensity, care] & 1.0456 & -2.3 & 1.0215 & -0.8 \\
\hline Conventional x [math intensity, care] & 1.0449 & -0.7 & 1.0217 & -0.2 \\
\hline \multicolumn{5}{|l|}{ Abilities: educational preparation (total) } \\
\hline Rel. math grade $x$ math intensity & 1.0418 & 6.2 & 1.0222 & 0.9 \\
\hline Constraints: social norms (total) & 1.0407 & 8.7 & 1.0263 & 10.1 \\
\hline Female $x$ diff. parents' approval & 1.0454 & -1.8 & 1.0215 & -0.8 \\
\hline Female $x$ diff. friends' approval & 1.0400 & 10.3 & 1.0277 & 13.2 \\
\hline Separate spheres (total) & 1.0424 & 5.0 & 1.0219 & 0.2 \\
\hline Preferences & 1.0422 & 5.2 & 1.0218 & -0.1 \\
\hline Earning well $x$ wage level & 1.0445 & 0.1 & 1.0216 & -0.4 \\
\hline Career $\mathrm{x}$ wage level & 1.0441 & 1.1 & 1.0216 & -0.5 \\
\hline Female $\mathrm{x}$ traditionalist $\mathrm{x}$ wage level & 1.0422 & 5.4 & 1.0224 & 1.4 \\
\hline Constraints (total) & 1.0446 & -0.1 & 1.0215 & -0.6 \\
\hline Pleasant work hrs. $\mathrm{x}$ overwork norms & 1.0446 & 0.0 & 1.0215 & -0.8 \\
\hline Fem. $x$ tradit. hhduties $x$ overw. norms & 1.0446 & -0.1 & 1.0219 & 0.2 \\
\hline \multicolumn{5}{|l|}{ Anticipated discrimination } \\
\hline Female $\mathrm{x}$ discrimination & $\begin{array}{r}1.0443 \\
48\end{array}$ & 0.6 & 1.0223 & 1.0 \\
\hline
\end{tabular}


Table A10: Proportion of students in major by gender.

\begin{tabular}{rrrrr}
\hline & \multicolumn{2}{c}{ Females } & \multicolumn{2}{c}{ Males } \\
& Proportion & s.e. & Proportion & s.e. \\
Pedagogy & .031 & .0029 & .004 & .0011 \\
Social work & .047 & .0036 & .009 & .0018 \\
Biology & .036 & .0035 & .006 & .0017 \\
Philology/cultural studies & .092 & .0050 & .024 & .0031 \\
State Teacher & .172 & .0034 & .021 & .0027 \\
Medical sciences & .065 & .0039 & .073 & .0027 \\
Arts, art sciences & .015 & .0019 & .038 & .0034 \\
Law & .051 & .0035 & .043 & .009 \\
Social science, political science & .065 & .0041 & .041 & .0039 \\
Economic sciences & .155 & .0065 & .116 & .0066 \\
Geography & .023 & .0028 & .023 & .0032 \\
History/Philosophy & .013 & .0017 & .017 & .0024 \\
Chemistry & .022 & .0025 & .032 & .0035 \\
Agronomy, Forestry & .016 & .0023 & .016 & .0030 \\
Mathematics & .021 & .0025 & .036 & .0038 \\
Civil engineering & .020 & .0026 & .054 & .0050 \\
Physics & .008 & .0014 & .041 & .0037 \\
Computer science & .021 & .0026 & .077 & .0055 \\
Industrial engineering & .024 & .0026 & .104 & .0062 \\
Mechanical engineering & .032 & .0033 & .158 & .0076 \\
Electrical engineering & .005 & .0013 & .047 & .0045 \\
\hline design, design & .021 & .0026 & .012 & .0024 \\
\hline
\end{tabular}

Note: Weighted estimates 


\begin{abstract}
${ }^{\mathrm{i}}$ We assign to this narrow, rationalistic conception of social norms that excludes intrinsic motives for norm following because we believe that broader definitions (Elster, 1989) blur the analytically useful distinction between norms and values.
\end{abstract}

ii The "Fachhochschulreife" allows students to enter all of the (few) majors that are offered at universities of applied sciences whereas the "fachgebundene Hochschulreife" restricts even the options students have at these low-tier colleges but instead allows students to enter a very small number of majors at full universities. Both of these types of non-standard leaving certificates categorically exclude students from the majority of majors.

iii These are: theology, library science, sports, administrative science, geology, veterinary medicine, and nutrition science.

${ }^{\text {iv }}$ Because the Micro Census provides income in 24 brackets, we impute the mean income within brackets as based on Glocker and Storck (2014).

${ }^{\mathrm{v}}$ Because we thereby measure potential approval based on persons who eventually choose that major, but expect the presence of selection bias, we are prone to underestimate the degree of gender bias in both directions. However, because we use the variable exclusively to model a decision between majors, this bias does not impact our estimates given that it is distributed uniformly across majors. It would not impact our results in any meaningful way either if the bias was distributed unequally across majors but in proportion to the level of the values of the measure. If (and only if) this measurement error followed a third distribution, our results would be biased. We see no reason why this assumption would be violated but want to point out that the interpretation of our results is conditional on the truth value of this assumption that we cannot test.

${ }^{v i}$ The conditional logit in this regard is more flexible than the closely related multinomial logit as it allows for variables to vary across choice options whereas the multinomial logit does not allow for alternative-specific variables. At the same time the conditional logit is more restrictive than the multinomial logit in that it forces the coefficients of these variables to be the same across all choice options, which the multinomial logit does not (Andreß et al., 1997). Our application differs from such that use direct measures for $\boldsymbol{X}_{i j}$ of majors not chosen by a person (Arcidiacono et al., 2012) in that variation in $\boldsymbol{X}_{i j}$ was generated by interacting observed person characteristics with observed major characteristics (Shauman, 2006).

vii When adding variables, percentage explained is computed as $\left[100 *\left(\left(\mathrm{OR}_{\mathrm{femalexpropemale}}\right.\right.\right.$ baseline -1$)$ $\left.\left.\left(\mathrm{OR}_{\text {femalexpropfemale added }}-1\right)\right) /\left(\mathrm{OR}_{\text {femalexpropfemale baseline }}-1\right)\right]$. When dropping variables, percentage explained is computed as $\left[-100 *\left(\left(\mathrm{OR}_{\text {femalexpropfemale fullmodel }}-1\right)-\left(\mathrm{OR}_{\text {femalexpropfemale dropped }}-1\right)\right) /\left(\mathrm{OR}_{\text {femalexpropfemale baseline }}-1\right)\right]$.

viii Because computation of marginal effects hinges on fixed effects that are not estimated in the conditional (fixed-effects) logit model, we report coefficients as odds ratios. These are sometimes interpreted in the vein of relative risks without justification due to the more intuitive appeal of the latter (Best and Wolf, 2010). Note that in our analysis the discrepancy between the odds interpretation and the relative risk interpretation is reduced to marginality because (a) even for the most popular majors in our study, baseline risks are small and (b) we scaled our explanatory variables in a way that yields odds ratios that do not diverge much from 1.

ix Even though we use fewer measures for essentialist norms and anticipated discrimination than for essentialist preferences, this does not advantage the preferences argument because essentialist preferences theory is put through a more rigorous test and estimates are more conservative as we do not have any measure available to condition on the micro-level mechanisms suggested by the essentialist norms and anticipated discrimination arguments such as "subjective expectation to receive approval from parents/peers" and "subjective expectation to be discriminated against", respectively. In this situation, we directly interacted gender with the theoretically relevant major characteristic. This allows all covariance to travel from cause to effect, irrespective of whether it actually goes through the hypothesized mechanisms or some other mechanism that links gender with gender biased norms / degree of discrimination. The same is not true for the essentialist preferences. Here only that part of the covariance that actually travels through the hypothesized micro-level mechanism (i.e. interest) is reflected in the reported 'percent explained'.

${ }^{\mathrm{x}}$ Students in Germany typically take their final exams in spring, select a college and college major in summer, and start their studies in fall. 